\title{
Identification of Archaeologically Relevant Areas Using Open Geodata
}

\author{
M. Fabian Meyer-Heß ${ }^{1}$ iD
}

Received: 11 March 2020 / Accepted: 8 July 2020 / Published online: 7 August 2020

(c) The Author(s) 2020

\begin{abstract}
Light detection and ranging (LiDAR) and digital terrain models (DTM) revolutionized archeological prospection in the last two decades. Using the new technique, comprehensive areal detections of archeological relief structures (field monuments) hidden under dense vegetation became possible and archeologists found new sites even in well-known areas. In times of Open Geodata policies, archeologists have access to geospatial data sets such as DTM. Assessing its full potential requires automated workflows, which is a recent research topic in archeological research. However, all approaches, both manually and automated, are affected by misclassifications caused by confusions of archeological and modern structures. Digital landscape models (DLM) help differentiating structures by their location. Concerning these data, only $74 \%$ of the total area of Westphalia and Lippe need archeological investigation, increasing precision of automated classification approaches.
\end{abstract}

Keywords Open geodata $\cdot$ Digital terrain model $\cdot$ Digital land use model $\cdot$ Archeological prospection $\cdot$ OBIA

\section{Abgrenzung archäologisch interessanter Gebiete mit Open Geodata}

\section{Zusammenfassung}

Light Detection And Ranging (LiDAR) und Digitale Geländemodelle (DTM) haben die archäologische Prospektion in den letzten zwei Jahrzehnten revolutioniert. Mit dieser Technik wurde es möglich, auch solche archäologischen Reliefstrukturen (Bodendenkmäler) flächendeckend zu erfassen, die von dichter Vegetation verdeckt sind. Dadurch werden selbst in altbekannten Untersuchungsgebieten immer wieder neue Funde gemacht. In Zeiten von Open Geodata haben Archäologen Zugang zu flächendeckenden raumbezogenen Datensätzen wie z.B. Digitalen Geländemodellen. Um ihr ganzes Potential auszuschöpfen sind automatisierte Workflows nötig, was ein aktuelles Forschungsthema ist. Alle Ansätze, ob manuell oder automatisiert, sind allerdings von Fehlklassifikationen beeinträchtigt, die auf Verwechslungen von archäologischen und modernen Strukturen zurückzuführen sind. Digitale Landschaftsmodelle (DLM) sind eine Möglichkeit, diese Strukturen anhand ihrer Lage auseinanderzuhalten. Unter Berücksichtigung solcher Daten kann die archäologisch zu prospektierende Fläche in Westfalen und Lippe auf 74\% reduziert werden, was die Qualität automatisierter Klassifikationsansätze insgesamt erhöht.

Schlüsselwörter Open Geodata · Digitales Geländemodell · Digitales Landschaftsmodell · Archäologische Prospektion · OBIA

M. Fabian Meyer-Heß

matthias.meyer@rub.de

1 Geomatics Group, Geography Department, Ruhr University Bochum, Bochum, Germany

\section{Introduction}

Major archeological discoveries are nowadays often made using digital terrain models (DTM) derived from LiDAR scans (light detection and ranging), for example Mayan cities in the Central American jungle (Canuto et al. 2018). These usually hide under dense vegetation but become visible in terrain models, which reveal the landscape under the vegetation. 


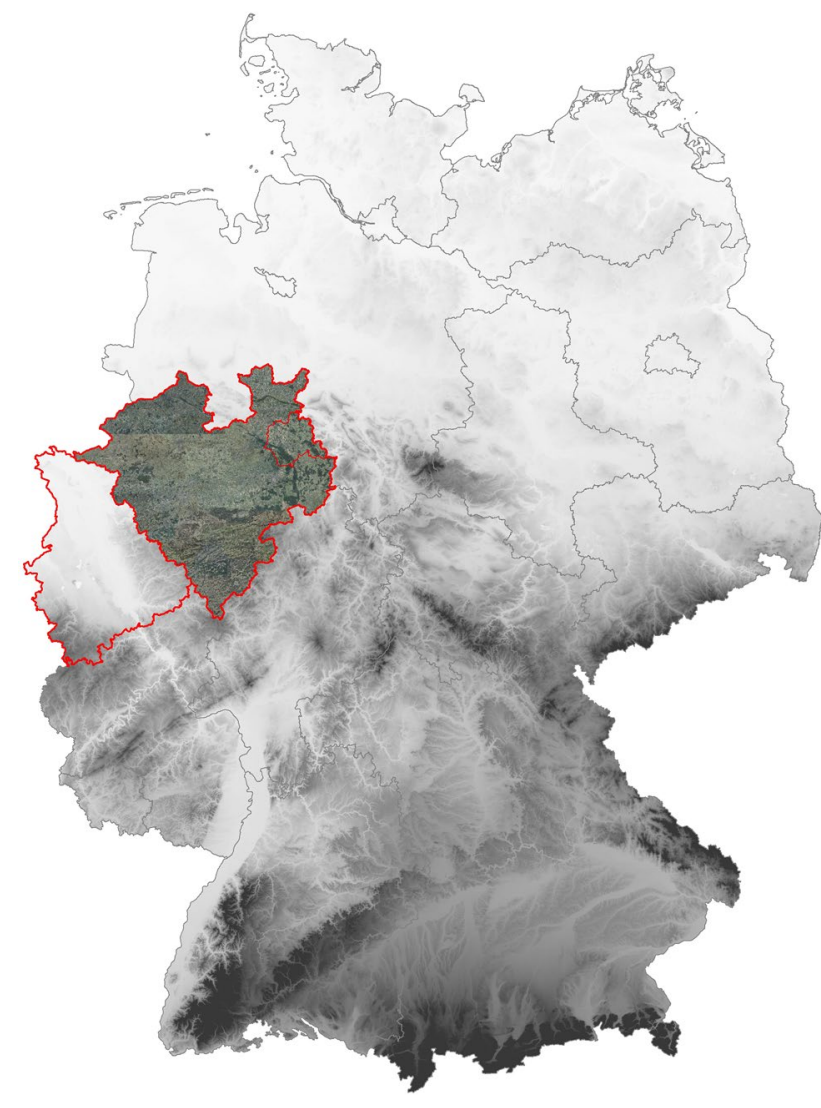

Fig. 1 Location of North Rhine-Westphalia (red). Its eastern part, Westphalia and Lippe (highlighted by photography) is the area of responsibility of the LWL Archeological Institute and the investigation area of this study (NASA and Land NRW)

This also applies to the region of Westphalia and Lippe, the investigation area of this study, which is part of the federal state of North Rhine-Westphalia (Fig. 1). For the whole federal state, different geodata such as terrain models are available. They support reconstructions of ancient landscapes, which is done by combining spatial distributions of discrete archeological findings (field monuments) to a wider image. This requires comprehensive areal detections using remote sensing data sets, which is a recent topic of research dealing with archeological prospection. For example, areas with ridge and furrow structures are remnants of early medieval fields and support detection of deserted settlements. The same applies to burial mounds from the Bronze and Iron Age. A closely related goal is contributing to databases such as FuPu-Delos, the database of archeological records, maintained by the Westphalian archeological institute (LWL-Archäologie für Westfalen 2019). It is used for documenting records and is the basis for preservation or for excavations if construction sites are likely to destroy field monuments (e.g. Klinke and Pfeffer 2018).

Field monuments in general are cultural heritage sites. Their conservation and management is a main task of archeological institutes, regulated by the monument protection act in North Rhine-Westphalia (Ministerium des Innern des Landes Nordrhein-Westfalen 2020). The available tools for prospection are numerous, but aerial archeology plays a decisive role for over a century. The distance to the surface allows seeing field monuments along with their relationship to the surrounding landscape (Braasch 1983). This is often the origin for close range prospections and finally excavations.

Aerial archeology uses variations in surface appearance for delineation of field monuments. Crop marks occur when vegetation is affected positively or negatively by underground structures, soil marks result from changes in soil conditions. Small changes in elevation cause shadows that are dependent on the position of the sun. When it comes to investigating vegetation-rich areas such as forests, aerial photography is not reliable because trees and leaves usually hide details on the ground. However, forests are very interesting for archeological prospection as field monuments are not being exposed to farming activities that would level them off over time.

This is where archeologists benefit most from LiDARbased DTM. The laser is little affected by vegetation as

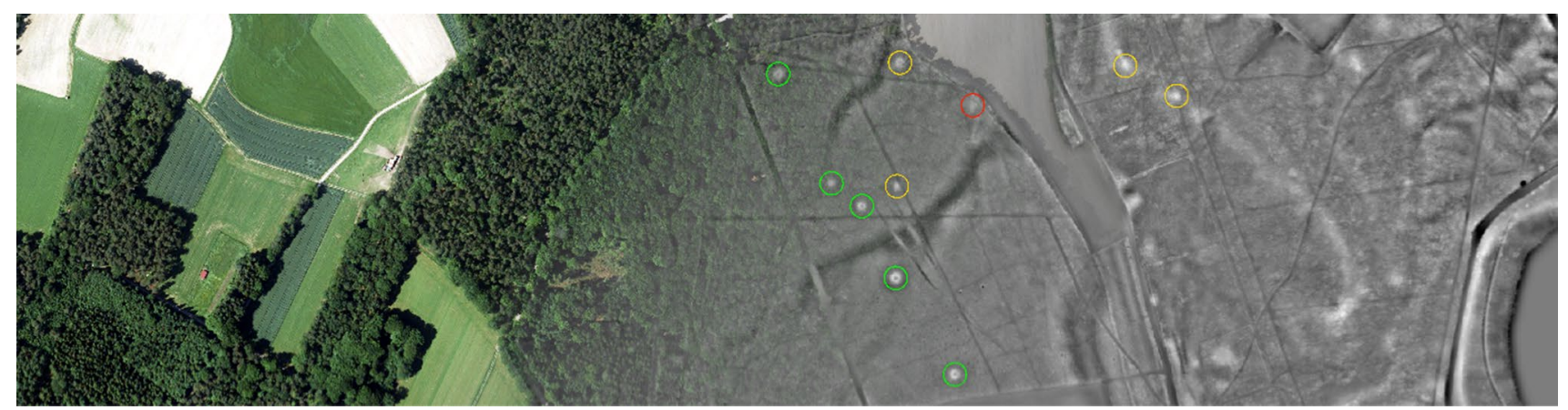

Fig. 2 Comparison of aerial photography and a micro-relief terrain model. Visibility of field monuments in the photography is limited to meadows and fields, whereas even subtle relief structures such as bur- ial mounds clearly stand out in the DTM. Once visible, they can be detected and highlighted using automated workflows such as OBIA (Land NRW) 
a part of the laser beam usually reaches ground level, allowing generation of extensive DTM independently of the land cover (Fig. 2). At least above-ground field monuments appear in these models. Most of the archeological structures cannot be identified in simple DTM as the contrast is too low to reveal subtle details. Therefore, common shaded relief visualizations are often used for interpretation. A digital sun is used to generate shadows, significantly increasing contrast. This is similar to aerial photographs revealing features by shadow marks.

The use of LiDAR-derived DTM in archeology and related research can roughly be divided into three sections. First approaches were made in the late nineties, assessing the potential of DTM for archeological prospection (e.g. Holden 2001; Motkin 2001; Holden et al. 2002; Sittler 2004; Devereux et al. 2005; Crutchley 2006; Risbøl et al. 2006; Bofinger et al. 2007; Doneus et al. 2008). At that time, terrain data was usually visualized as shaded relief, which is intuitive and was already known from cartography (Hake et al. 2002). However, articles soon pointed out that linear structures aligning with the direction of the (digital) sun remain invisible. Therefore, different relief visualization techniques were developed that are capable of showing all subtle structures at once (e.g. Doneus and Briese 2006; Devereux et al. 2008; Hesse 2010; Zakšek et al. 2011; Doneus 2013; Hesse 2016. See Kokalj and Hesse (2017) for comparison and guide). In recent years, research increasingly focusses on developing approaches regarding automated detections using a variety of techniques, such as Object-based Image Analysis (OBIA, Fig. 2) (e.g. Vletter 2015; Freeland et al. 2016; Sevara et al. 2016; Cerrillo-Cuenca 2017; Meyer et al. 2019), Template Matching (e.g. de Boer 2007; Schneider et al. 2015; Trier et al. 2015) or, most lately, Machine Learning in all its different forms (e.g. Trier et al. 2018; Verschoofvan der Vaart and Lambers 2019) as well as combinations or other techniques (e.g. Heinzel and Sittler 2010; Davis et al. 2019). Automation in general is necessary as the growing amount of data cannot be handled manually anymore.

In general, approaches for both manual and automated classifications of field monuments are affected by misclassifications (false positives) due to confusions of field monuments and modern structures. This especially applies for simple monuments like mounds and pits. Additional information, such as the location and the surrounding land use, are helpful for differentiating structures that are morphologically identical. For example, mounds in forests are much more interesting than those on (former) industrial sites. This is based on the assumption that ancient field monuments are unlikely to be preserved in areas that were (or still are) exposed to human relief-changing activities in modern decades, which for example include sealed areas as well as surroundings of streets and railway tracks. Therefore, adding land use data sets to classification approaches, either by overlaying other data or by limiting search algorithms to interesting areas, seems promising, not only for DTM but for remote sensing data in general. Overlaying different layers for spatial filtering is commonly known as overlay analysis or sieve mapping, which is nowadays used for GIS-based site analysis.

Land use classifications are often based on interpretation of aerial and satellite imagery. For this purpose, however, the semantical land use is important, which can literally hide under vegetation. Therefore, this project uses governmental data sets provided by the OpenGeodata.NRW initiative. Not only are they derived from digital orthophotos (DOP), but also from field surveys and cadastral data as well (Bezirksregierung Köln 2019).

Although these kinds of data are available in all federal states, the related data policies are still on a way towards OpenGeodata. If data were accessible, they already became part of archeological prospection. For example, Brouwer (2015) used land use data for a similar approach in a delimited investigation area in Westphalia for ridge and furrow detection. Noack (2019) carried out a similar project in the Prignitz region in Brandenburg using a land use model for limiting the investigation area. Schmidt et al. 2018 used land use data for reconstructing the pre-modern topography around the Fossa Carolina, a medieval canal bridging the Central European watershed in Treuchlingen, by removing the imprint of modern structures from a DTM. Directly related to this article is Meyer et al. (2019), where polygonal land use data were already used for automated detection approaches in Westphalia.
Table 1 Overview of the main data sets

\begin{tabular}{|c|c|c|}
\hline & DTM & DLM \\
\hline Provided as & xyz-files; point data & $\begin{array}{l}\text { Shapefiles containing } \\
\text { point, line or polygon } \\
\text { features }\end{array}$ \\
\hline Date of acquisition & Continuously updated & Continuously updated \\
\hline Preprocessing & Filtered, last pulse, interpolated & \\
\hline Point spacing, distribution & Regular grid, $1 \mathrm{pt} / \mathrm{m}^{2}$ & \\
\hline
\end{tabular}


Table 2 Line feature taken from the BasisDLM

\begin{tabular}{lllllllll}
\hline Shape & OBJART & OBJART_TXT & BKT & ELK & GLS & NRB & SPW & ZUS \\
\hline Polyline & 42014 & AX_Bahnstrecke & 1100 & 2000 & 1000 & 2961 & 1000 & 2100 \\
\hline
\end{tabular}

Irrelevant or empty attributes are not displayed
Although the benefit of using these land use models seems obvious, an application to the entire region of Westphalia and a detailed analysis and quantification are still pending. Furthermore, data sets with a similar structure might become accessible in other regions as well. Therefore, this article (1) proposes a workflow for a delimitation of archaeologically relevant areas, that could be applied to other federal states, and (2) quantifies the benefit regarding the reduction of investigation area, the number of misclassifications and the overall improvement of a sample classification.

\section{Data}

The European Union launched their INSPIRE initiative in 2007 to ease access to geodata for all kinds of purposes (European Commission 2007). Implementing its demands on a regional scale, the federal government of North RhineWestphalia started their OpenGeodata.NRW program in 2017 , providing a variety of continuously updated spatial data sets free of charge. A DTM, a DLM (digital landscape model) and two small data sets including relief-manipulated areas were used (LAND NRW 2019).

The DTM is provided in text files containing last pulse point data in an interpolated regular grid (secondary DTM) of $1 \mathrm{pt} / \mathrm{m}^{2}$. Non-ground points, such as buildings, are not included. The data was not explicitly acquired for archeological purposes and the quality is far away from today's standards. However, it has turned out to be precise enough for detecting field monument at this scale (Table 1).

The DLM is provided in 41 shapefiles, each of which contains a group of land use types (vegetation, settlement, transportation etc.) in suitable geometries (point, line or polygon). The included features describe the landscape in around 84 object classes and several subclasses. These are defined in a catalog that contains explanations to the attributes and other details (AdV 2008). Features are stored as shown in Table 2: The general attributes OBJART and OBJART_TXT identify the polyline feature as a railroad track in general. BKT specifies the track in this case as a regular railroad $(\mathrm{BKT}=1100)$ that is not electrified $(\mathrm{ELK}=2000)$, singletracked $(\mathrm{GLS}=1000)$ with standard gauge $(\mathrm{SPW}=1000$, $1435 \mathrm{~mm}$ in Germany). NRB is a unique identifier and ZUS provides additional information, in this case that the track is not in use anymore.
While processing these data (Sects. 3.1-3.3), it became obvious that mine dumpsites, landfills etc. would not be handled correctly, as the attributes do not provide any information regarding time and the model only contains active parts of dumpsites (current sites). This especially applies to old mine dumps in the Ruhr district: these were often closed and afforested decades ago and cannot be distinguished from regular forests anymore.

Encountering this, two additional data sets were used (Sect. 3.4): The 'Information System Resource Map Soil' (ISRK LG) from the Geological Survey NRW (Geologischer Dienst Nordrhein-Westfalen 2019) and the 'Landfill Data Information System' (ADDISweb) from the State Office for Nature, Environment and Consumer Protection NRW (LANUV NRW 2019). Both provide shapefiles and geodatabases containing areas where material was extracted or dumped, which therefore do not contain field monuments. These data sets are still being constructed and there are still dumpsites missing but using them is nevertheless beneficial. Using data from the OpenStreetMap-project is not an option because it lacks temporal information in the same way as the BasisDLM.

Evaluation and some detailed processing decisions (e.g. Sect. 3.5) are based on archeological records taken from FuPu-Delos, the database of archeological records in Westphalia. These data have some drawbacks regarding spatial precision, destroyed monuments and completeness (Sect. 4) (LWL-Archäologie für Westfalen 2019).

Data were processed using a combination of QGIS, ArcGIS Desktop, ArcGIS Pro and Python. Except parts of the tasks described in Sect. 3.5, everything can be done using basic GIS-functions like selections and buffering. The mound classification in Sect. 4 was performed using eCognition.

\section{Extraction of a Positive Layer}

This section proposes a workflow for going through all object classes to delimit archeological relevant areas. Shapefiles and the included features are sorted in three categories: areas where field monuments can be preserved are called positive and used to generate an initial Positive Layer. Areas that most likely do not contain monuments are called negative. In general, negative areas are subtracted from positive. The result is the final Positive Layer. However, some data sets contain both positive and negative features. In these 


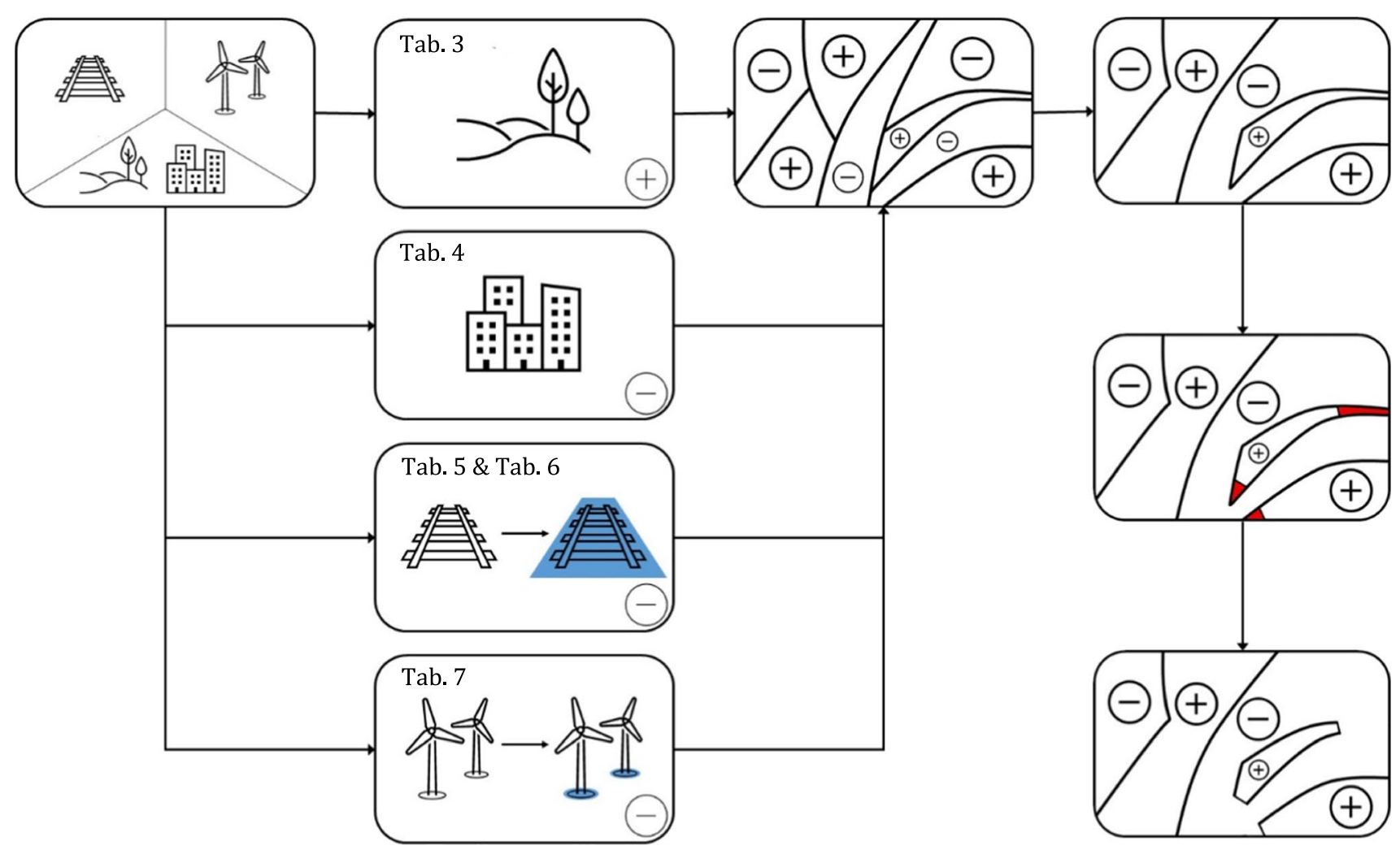

Fig. 3 Overview of the workflow. The input data (1st column) are divided into positive and negative (2nd column), individually buffered (blue), intersected (3rd column) and finally reshaped (4th column) to generate the final Positive Layer (bottom right)

Table 3 Generation of the initial Positive Layer

\begin{tabular}{lll}
\hline Layer & Objektart (GER) & Object class (EN)/differentiation/annotation \\
\hline veg01_f & Landwirtschaft & Agriculture \\
veg02_f & Wald & Forest \\
veg03_f & Gehölz & Wood/thicket \\
& Heide & Heathland \\
& Moor & Bog/wetland \\
& Sumpf & Swamp \\
& Unland, vegetationslose Fläche & Wasteland, area without vegetation_only positive if located \\
& & outside of settlements (Ortslage, sie01_f), otherwise nega- \\
& & tive \\
veg04_f & Vegetationsmerkmal & Other vegetation \\
\hline
\end{tabular}

cases, both kinds of features need to be separated before subtraction. The positive features, that are removed from the negative dataset before its subtraction, are highlighted in gray. Furthermore, some objects or shapefiles are left aside completely, as they do not contain information regarding land cover (e.g. the legal status) or are not present in the current Positive Layer anymore. These are not listed in the following sections to keep the tables short.

For practical reasons, the workflow (Fig. 3) does not follow the object classes but the shapefiles, which is why there are three major steps: at first, polygon features (e.g. forests, pastures and settlements) are considered and an initial Positive Layer generated, a preliminary version of which was already used in Meyer et al. (2019). From this layer, terrain imprints of line and point features are subtracted (step two and three). However, their imprints are not recorded and need to be generated by buffering the features using a suitable distance for each object class or subclass. Once this is done, the imprints are available as polygon features and can be subtracted. 


\subsection{Polygon Features}

At first, all object classes representing unsealed areas, for example agriculture, meadow and forest are declared as positive and merged. However, wastelands are only flagged as positive if they are not located in settlements. This step creates an initial Positive Layer, of which all the negative layers will be subtracted (veg01_f, veg02_f, veg03_f, veg04_f, Table 3).

Near-natural areas are subtracted at first. Waterbodies include both natural and man-made areas like rivers, lakes and basins of harbors as well as channel bridges (and the covered area below) and ambiguous classifications of waterbodies (gew01_f). Secondly, rock formations and bare rock are removed (rel01_f).

The next step is to subtract settlement areas. Compact built-up areas could be subtracted completely. On the one hand, doing so would remove misclassified urban woods. On the other hand, this would erase interesting green areas close to settlements as well. Therefore, it is used to differentiate wastelands (see above, sie01_f). Settlement areas are not necessarily sealed but flagged negative as they are too much associated with settlements to reveal new discoveries. The chance of generating misclassifications is significantly

Table 4 Polygonal negative areas

\begin{tabular}{|c|c|c|}
\hline Layer & Objektart (GER) & Object class (EN)/differentiation/annotation \\
\hline veg03_f & Unland, vegetationslose Fläche & $\begin{array}{l}\text { Wasteland, area without vegetation - only negative if lo- } \\
\text { cated inside of settlements (Ortslage, sie } 01 \text { f), otherwise } \\
\text { positive }\end{array}$ \\
\hline \multirow{3}{*}{ gew01_f } & Fließgewässer & Flowing water \\
\hline & Hafenbecken & Harbor basin \\
\hline & Stehendes Gewässer & Stagnant water \\
\hline rel01_f & Felsen, Felsblock, Felsnadel & Rock, boulder, rock needle \\
\hline \multirow{9}{*}{ sie02_f } & Bergbaubetrieb & Mining facility \\
\hline & Fläche besonderer funktionaler Prägung & Special-use area \\
\hline & Fläche gemischter Nutzung & Mixed-use area \\
\hline & Friedhof & Cemetery \\
\hline & Halde & Dumpsite (active) - see 3.4 \\
\hline & Industrie und Gewerbefläche & Industrial and business area \\
\hline & Sport-, Freizeit- und Erholungsfläche & Sport and recreation area \\
\hline & Tagebau, Grube, Steinbruch & Open pit and stone pit \\
\hline & Wohnbaufläche & Residential area \\
\hline \multirow{6}{*}{ sie03_f } & $\begin{array}{l}\text { Bauwerk oder Anlage für Industrie und } \\
\text { Gewerbe }\end{array}$ & Building or facility for industry and commerce \\
\hline & \multirow{2}{*}{$\begin{array}{l}\text { Bauwerk oder Anlage für Sport, Freizeit } \\
\text { und Erholung }\end{array}$} & Building or facility for sport and recreation \\
\hline & & Wildgehege / Game reserve \\
\hline & $\begin{array}{l}\text { Historisches Bauwerk oder historische } \\
\text { Einrichtung }\end{array}$ & Historical building or historical facility \\
\hline & $\begin{array}{l}\text { Sonstiges Bauwerk oder sonstige } \\
\text { Einrichtung }\end{array}$ & Other building or other facility \\
\hline & Vorratsbehälter, Speicherbauwerk & Reservoir, storage structure \\
\hline \multirow{2}{*}{ sie04_f } & Hafen & Harbor \\
\hline & Schleuse & Lock \\
\hline \multirow{2}{*}{ ver01_f } & Platz & Square \\
\hline & Straßenverkehr & Road traffic \\
\hline ver03_f & Bahnverkehr & Rail traffic \\
\hline ver04_f & Flugverkehr & Air traffic \\
\hline \multirow{4}{*}{ ver06_f } & Bahnverkehrsanlage & Facility associated with rail traffic \\
\hline & Bauwerk im Gewässerbereich & Building associated with waters \\
\hline & Bauwerk im Verkehrsbereich & Building associated with traffic systems \\
\hline & Flugverkehrsanlage & Facility associated with air traffic \\
\hline
\end{tabular}




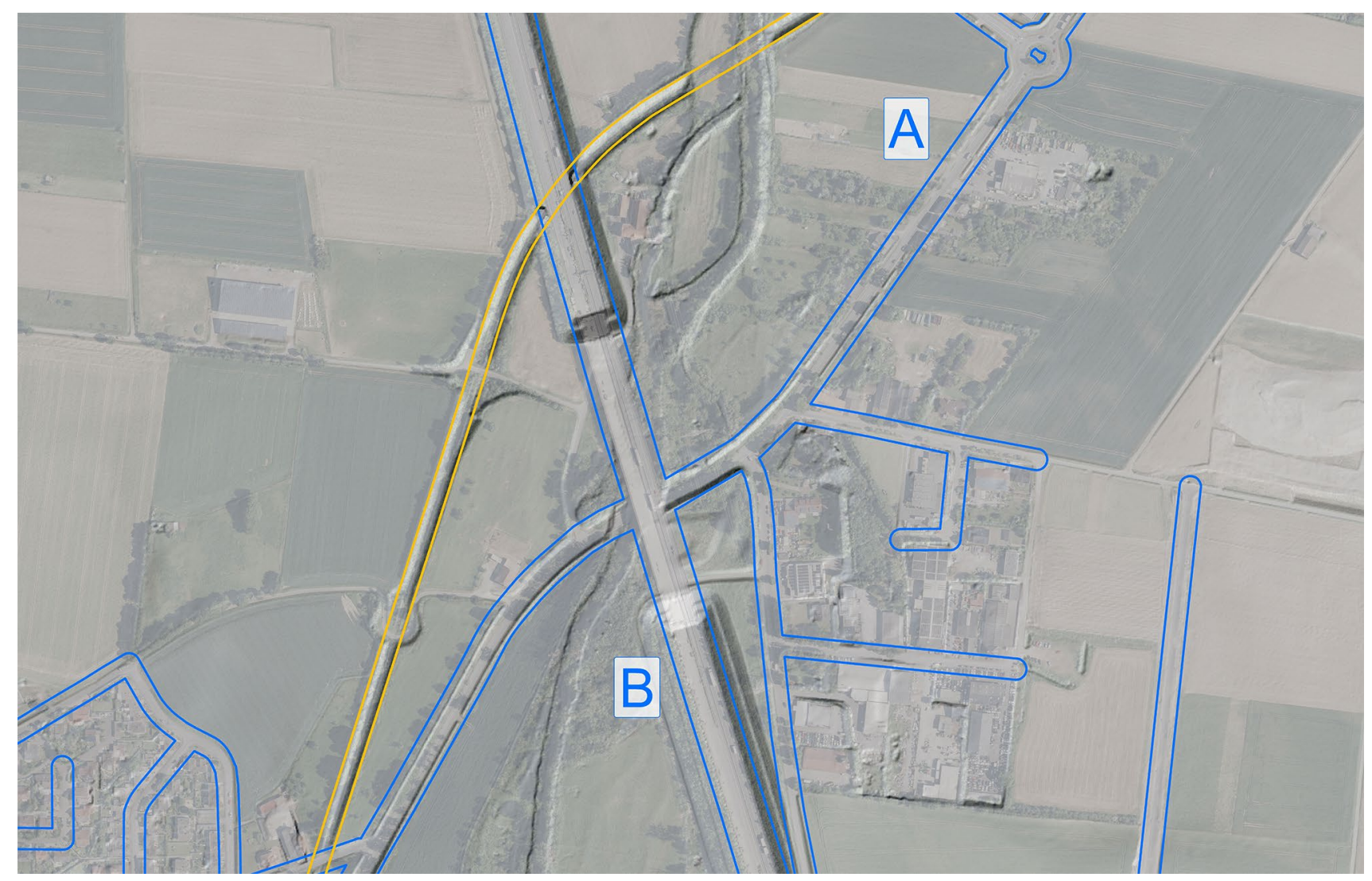

Fig. 4 Hillshade-DTM with transparent Digital Orthophotos, overlayed by buffered line features. The buffer area around the singletracked railway from Table 2 adequately represents its relief imprint (orange). The same applies to the residential streets (blue, A). However, sufficiently buffering height changing embankments using a static buffer distance is impossible (blue, B) (Land NRW) higher. In summary, these are mines as well as industrial, business, recreation and residential areas (sie02_f). The same applies for buildings of the same categories, with the exception of game reserves, whose relief does not appear to be manipulated. Some of which are subtracted anyway as they are simultaneously flagged as recreation area. Historical buildings are not subtracted for obvious reasons (sie03_f). Along with settlement areas, harbors and locks are removed. Some of these include irrelevant green areas that are part of the previous Positive Layer (sie04_f).

Finally, polygons representing areas for road, rail and air traffic are subtracted, including bridges and tunnels as well as lawns of airfields. As bridges and tunnels are not present in the DTM, subtractions apply to areas under or above these constructions. The latter can be inspected manually and added again in case they are unsealed. Although areas under bridges are often unsealed, they are probably affected by corresponding construction sites and therefore removed without further investigation. The same applies to lawns associated with airfields. They are often unsealed but as being part of the taxiways completely smoothed (ver01_f, ver03_f, ver04_f, ver06_f). A complete list of all assignments is provided in Table 4.

\subsection{Line Features}

Line and point features lack of width and therefore of area, making simple subtractions of the corresponding shapefiles impossible. In terms of GIS, these need to be buffered using a suitable radius for every object class or subclass that matches the imprint of the structures. Doing so is either based on width-describing attributes or on visual inspection of the DTM in relatively plain landscapes to estimate the terrain manipulation. Embankments of varying height and width can hardly be considered as determining a single radius is impossible (Fig. 4).

At first, all feature classes are clipped to the extent of Westphalia and underground features are removed. This also deletes streets located above subways, which is irrelevant in practice as subways run in cities and therefore not under positive areas.

Secondly, the data is clipped to the Positive Layer from Sect. 3.1, reducing the number of line features significantly. 
Table 5 Buffering of streets depending on type (WDM) and width (FSZ) for generating negative areas

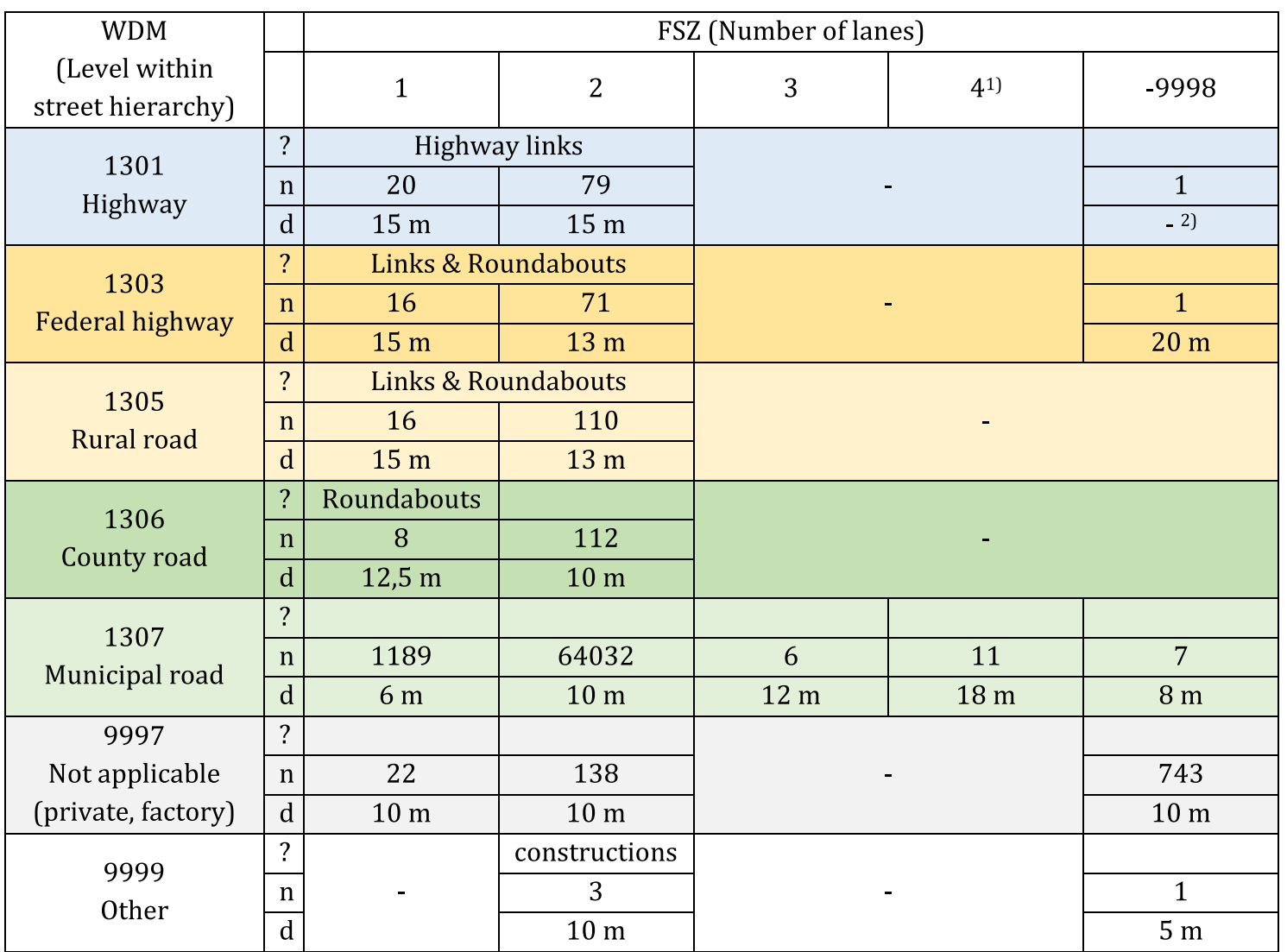

Background colors represent the street hierarchy rank and roughly correspond to the color scheme of German traffic signs. ?= mostly consisting of $(\ldots) ; n=$ number of features; $d=$ buffer distance. 1) FSZ 5 not present anymore; 2) already buffered

Table 6 Buffering of line features for generating negative areas

\begin{tabular}{|l|l|l|c|}
\hline \multirow{2}{*}{ Layer } & \multicolumn{1}{|c|}{ Objektart (GER) } & \multicolumn{1}{c|}{ Object class (EN) } & Radius \\
\hline ver02_l & Fahrwegachse; Weg, Pfad, Steig & Road axis; way, path, trail & $6 / 8 \mathrm{~m}$ \\
\hline \multirow{2}{*}{ ver03_l } & Bahnstrecke & Railway line & $8 / 10 \mathrm{~m}$ \\
\cline { 2 - 4 } & Seil- und Schwebebahn & Elevated railway & $3 \mathrm{~m}$ \\
\hline \multirow{2}{*}{ gew01_l } & Gewässerachse & Watercourse & $10 / 5 \mathrm{~m}$ \\
\hline \multirow{2}{*}{ rel01_l } & Damm, Wall, Deich & Dam, bank, dike & - \\
\cline { 2 - 4 } & Felsen & Rock & $3 \mathrm{~m}$ \\
\hline \multirow{2}{*}{ sie03_l } & Transportanlage & Pipeline (e.g.) & - \\
\cline { 2 - 4 } & Leitung & Electric power transmission & $5 \mathrm{~m}$ \\
\cline { 2 - 4 } & Historisches Bauwerk oder Einrichtung & Sistorical building or facility & - \\
\cline { 2 - 4 } & Sonstiges Bauwerk oder Einrichtung & Other building or other facility & $1 \mathrm{~m}$ \\
\hline \multirow{2}{*}{ ver06_l } & Bauwerk im Gewässerbereich & Building associated with waters & $3 \mathrm{~m}$ \\
\hline
\end{tabular}

This process removes only those lines (and parts of them) that are inside of a positive polygon. However, line features often match the border of two polygons and only touch the positive one. These are kept for investigation, as otherwise it would not be possible to buffer and remove their imprint. 
Streets are buffered first. Roughly half of them have an attribute describing the width of the driving surface (BRF). These diameters are used as buffer radii to consider bicycle tracks, pavements, slopes, woods and general changes in width. A Python script is useful to buffer each feature with its specific attribute value. Streets without such information need to be assessed differently. A combination of attributes describing the rank within the street hierarchy (WDM, e.g. highway or municipal) and the number of lanes (FSZ) helps estimating suitable buffer radii. All combinations are listed in Table 5. Manual assignment of values is done in the same way as with the Python script (ver01_l).

Small roads and paths are handled the same way (Table 6). This time, the width describing attribute (BRV) is always available and can be used directly as buffer radii. By using a diameter as radii again, slopes and woods along the roads are already covered (ver02_l).

Rail transportation systems are the last type of transportation infrastructure to be considered. The GLS attribute (number of rails) allows discriminating between singleand double tracked railways and buffering these separately. This approach differs from the one used by Noack (2019), who used the structure gauge for buffering. This turned out to be insufficient for Westphalia as the imprint of the railways is usually larger, for example including power masts along the track (Fig. 4). Elevated railways usually run on routes invisible in the terrain model and lack of an adequate attribute for buffering. However, field monuments are quite unlikely to be found between the masts of the tracks. Furthermore, these are usually located alongside the track, requiring generous buffering equal to single tracked railways (ver03_l).

Classified width information can also be used for rivers. In this case, the attribute BRG has the values (up to) 3, 6 or $12 \mathrm{~m}$, which are directly used as radii (gew01_l).

Dikes and similar structures usually run along rivers and canals. An attribute-based differentiation between features of different types is not reasonable. Therefore, large dikes belonging to big rivers and canals are selected manually and buffered separately. The remaining smaller features are buffered with half the radius. In this way, the removal of too many positive areas can be avoided. The object type rock is ignored, as buffering with a single radius is difficult and furthermore many large rock areas do not occur in the DLM at all (rel01_l).

Table 7 Buffering of point features for generating negative areas

\begin{tabular}{|c|c|c|c|}
\hline Layer & Objektart (GER) & Object class (EN) & Radius \\
\hline \multirow{3}{*}{ gew02_p } & Gewässermerkmal: Quelle & Water related: Well & $11 \mathrm{~m}$ \\
\hline & Gewässermerkmal: Waterfall & Water related: Waterfall & - \\
\hline & Wasserspiegelhöhe & Water surface level & - \\
\hline rel01_p & $\begin{array}{l}\text { Höhleneingang; Felsen, Felsblock, } \\
\text { Felsnadel }\end{array}$ & Cave entry; Rock, boulder, rock needle & $11 \mathrm{~m}$ \\
\hline \multirow{5}{*}{ sie03_p } & $\begin{array}{l}\text { Bauwerk oder Anlage für Industrie } \\
\text { und Gewerbe }\end{array}$ & $\begin{array}{l}\text { Building or facility for industry and } \\
\text { commerce }\end{array}$ & \\
\hline & \begin{tabular}{l|l} 
& BWF: Windkraftanlagen
\end{tabular} & Wind turbine & $20 \mathrm{~m}$ \\
\hline & \begin{tabular}{|l} 
BWF: Freileitungsmast; Funkmast; \\
Schornstein, Schlot, Esse; \\
Stollenmundloch; Schachtöffnung
\end{tabular} & $\begin{array}{l}\text { Transmission tower; Radio mast; Chim- } \\
\text { ney; Vertical mine entrance; Shaft en- } \\
\text { trance }\end{array}$ & \multirow{2}{*}{$10 \mathrm{~m}$} \\
\hline & $\begin{array}{l}\text { Vorratsbehälter, Speicherbauwerk; } \\
\text { Transportanlage; Sonstiges Bauwerk } \\
\text { oder sonstige Einrichtung }\end{array}$ & $\begin{array}{l}\text { Reservoir, storage structure; Transpor- } \\
\text { tation facility; Other building or other } \\
\text { facility }\end{array}$ & \\
\hline & $\begin{array}{l}\text { Historisches Bauwerk oder } \\
\text { Einrichtung }\end{array}$ & Historical building or facility & 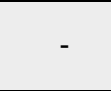 \\
\hline sie05_p & Turm & Tower & $11 \mathrm{~m}$ \\
\hline \multirow[t]{2}{*}{ ver06_p } & $\begin{array}{l}\text { Bauwerk im Verkehrsbereich; } \\
\text { Straßenverkehrsanlage; } \\
\text { Bahnverkehrsanlage; Bauwerk für den } \\
\text { Schiffsverkehr }\end{array}$ & $\begin{array}{l}\text { Building associated with traffic systems; } \\
\text { Facility related to street traffic; Facility } \\
\text { associated with rail traffic; Building re- } \\
\text { lated to shipping transport }\end{array}$ & \\
\hline & Flugverkehrsanlage & Facility associated with air traffic & $20 \mathrm{~m}$ \\
\hline
\end{tabular}




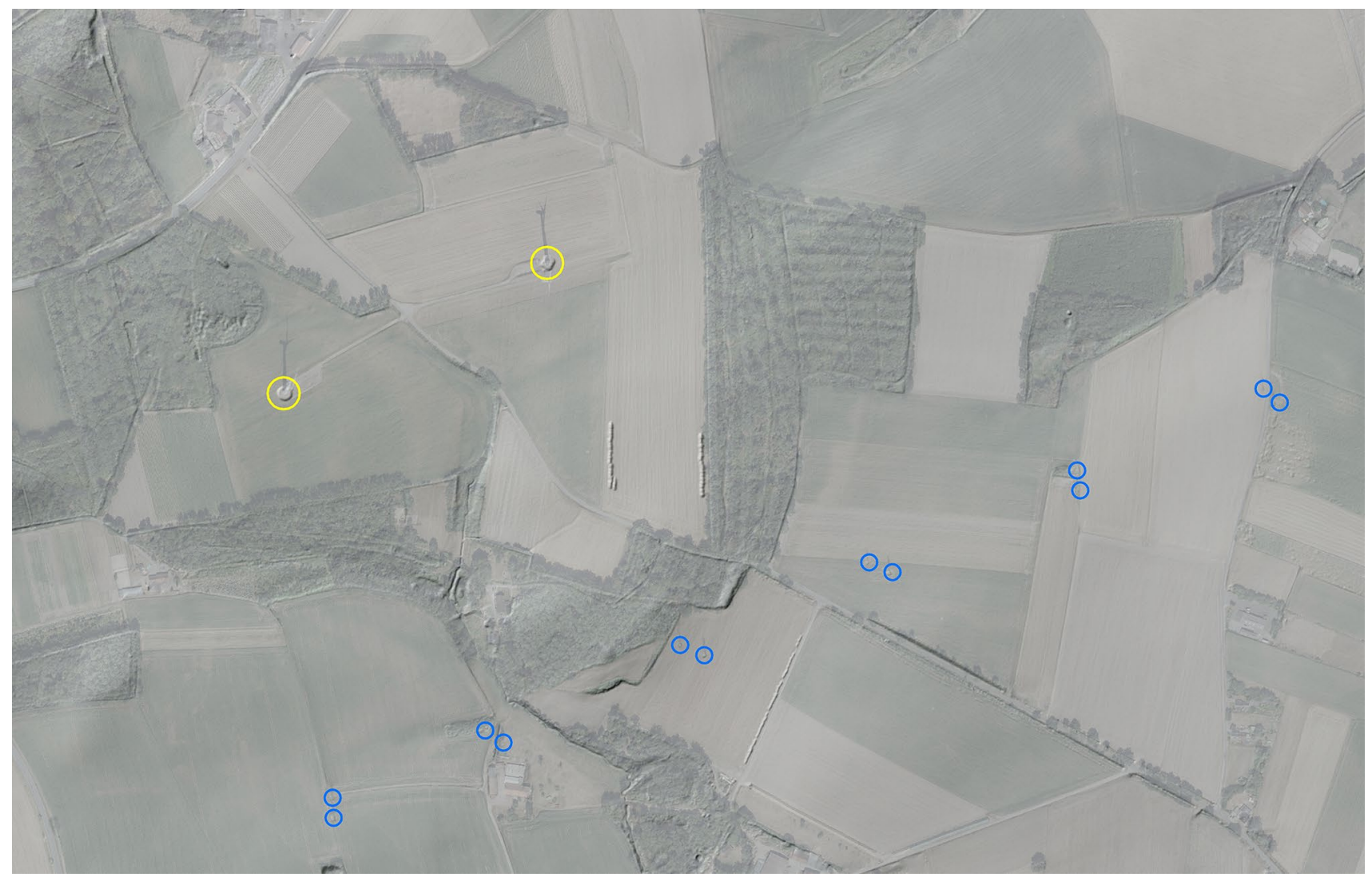

Fig. 5 Hillshade-DTM with transparent Digital Orthophotos, showing buffered areas around two wind turbines (yellow) and transmission towers (blue) (Land NRW)

Regarding the settlement sector, transport facilities including pipelines and boundaries such as fences or walls need consideration. The object classes are buffered separately according to their function (BWF). Power lines are ignored, as they run overhead and only their masts manipulate the terrain (similar to elevated railways), which are available as single point features. Historical features are again ignored (sie03_1).

Finally, the feature class used at the beginning for determination of underground features is checked for previously untouched features. These mainly consist of structures associated with waterbodies, including remains of bridges, the centers of which is already removed while buffering the underlying area, and wave-breakers in rivers. A buffer radius of $3 \mathrm{~m}$ is applied to these remaining features (ver06_1).

\subsection{Point Features}

Rejecting point features and their surrounding is done in almost the same way as for lines. At first, all data sets are clipped to the extent of Westphalia but not to the previous Positive Layer. This avoids (e.g.) wind turbines not being buffered if its point feature is already covered by the corresponding road buffer. All buffer distances are listed in Table 7.

Water related points are the first to be buffered, consisting of wells, waterfalls and measurement locations of water levels. Only the first of these are considered. On the one hand, the imprints of untouched wells are invisible in the $1 \mathrm{~m}$-DTM. On the other hand, many wells are integrated into small buildings such as brick basins, which have significant impacts on the relief. Furthermore, the points are often placed a few meters away from their corresponding river line feature. Addressing this, the radius is set to $11 \mathrm{~m}$, which closes the gap between a digital well and its adjacent river in most cases (gew02_p).

Buffering cave entries and rock formations is as difficult as buffering some of the lines, as only a few features allowed determining a radius. In addition, cave entries are barely visible in terrain models. However, field monuments are unlikely to be found in these rocky areas and therefore, the radius is set to $11 \mathrm{~m}$ again (rel01_p).

Processing settlement-related points looks like a tedious task due to the large number of different objects. However, the already known radius of $11 \mathrm{~m}$ is reasonable for all classes. Objects requiring larger radii are probably 


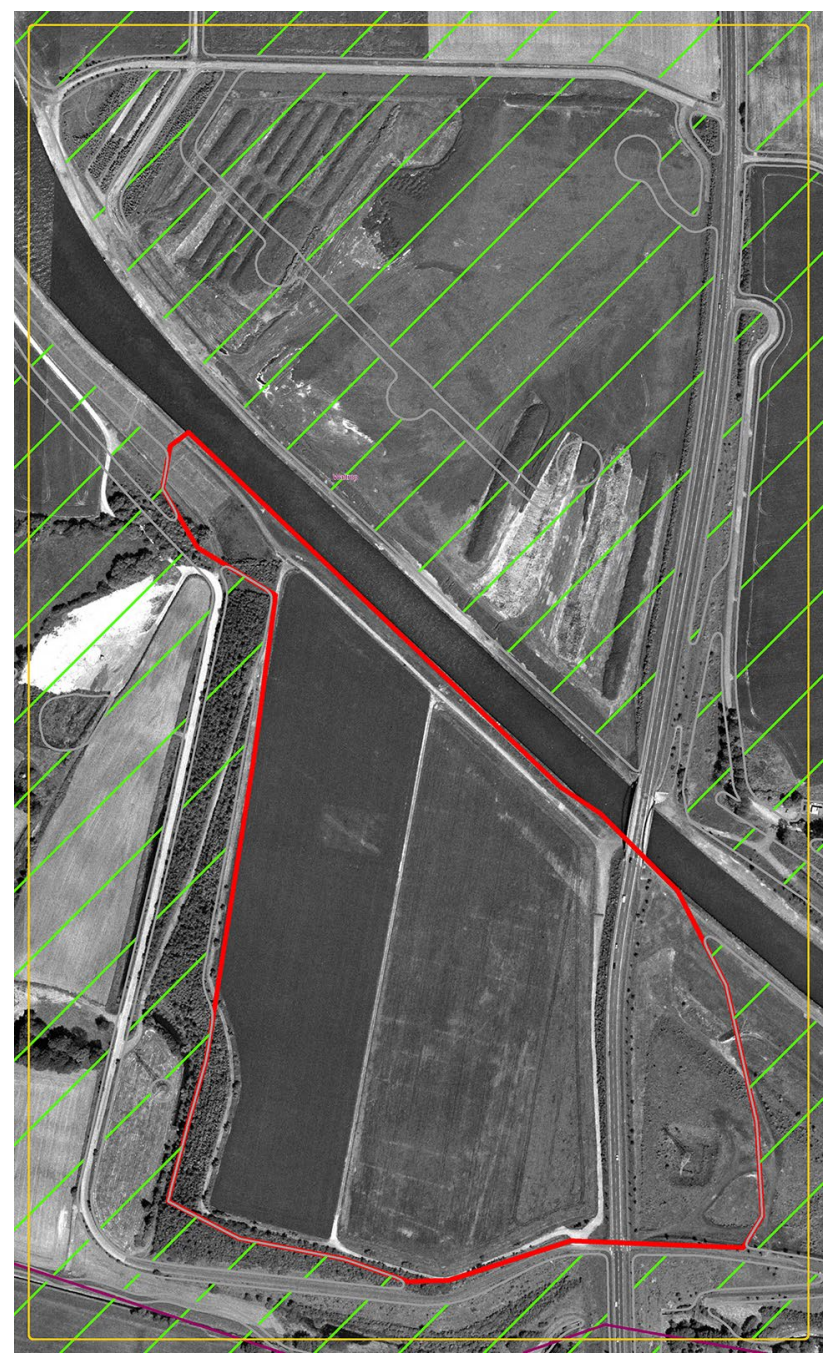

Fig. 6 Orthophoto from 1996, illustrating possibilities and limitations of ISRK LG and ADDISweb. Both areas inside the yellow box were exposed to relief manipulation in the past and are classified as recent agricultural areas in the DLM. However, only the area inside of the red polygon is present in one of the dumpsite data sets and removed from the Positive Layer (green). As a consequence, not all, but most closed dumpsites are removed (Land NRW)

recorded as polygons. One exception refers to wind turbines. These are assigned with $20 \mathrm{~m}$, which usually corresponds to the spacing between the foundations of lattice towers and is adequate for steel tube tower as well (Fig. 5, sie03_p). As already known, historical buildings were kept untouched. Other towers are buffered using a distance of $11 \mathrm{~m}$ (sie05_p).

Belonging to aviation-related objects, helicopter landing sites are rejected using a $20 \mathrm{~m}$ buffer again. They are the last object class of interest, the other classes in this features class are already excluded (ver06_p).

\subsection{Information from Further Data Sets}

Both additional data sets, ISRK LG and ADDISweb, contain areas where material was dumped or removed at some point in recent times. Their quality regarding spatial precision and attribution is significantly worse than that of the DLM, but nevertheless they complement its information and help removing closed dumpsite as well (Fig. 6). However, the lack of attributes does not allow further classification. Therefore, both data sets are merged and subtracted from the previous Positive Layer.

This Positive Layer could already be used for archeological prospection. However, numerous remaining polygons are strongly fragmented after they have been cut several times. Cleaning up the Positive Layer is therefore advisable.

\subsection{Handling of Narrow and Thin Areas}

Based on the assumption that monuments are not preserved in areas that are too thin or too small to contain even a single field monument, polygons with a width or size below a certain threshold are removed. However, doing this without reorganizing and reshaping the existing polygons first, is not reasonable:

1. Especially areal field monuments are independent of modern land cover boundaries. Therefore, adjacent polygons of differing land use are dissolved. For example, this ensures that a small remaining forest, adjacent to a meadow, is not removed.

2. Multipart features are converted into single part features. Not doing so would have the opposite effect of (1): the area of isolated parts of polygons would not be calculated separately.

3. Numerous (dissolved single part) polygons are interesting as a whole but have narrow, filament-shaped parts that need to be removed. ArcGIS Pro provides a tool for delimiting these parts using a threshold. As burial mounds are the smallest recurring field monument in Westphalia that are detectable in terrain models of this quality, the threshold is set to $8 \mathrm{~m}$. This represents the minimum diameter of relatively intact burial mounds and corresponds to the minimum area of their class in the mound classification including a little tolerance. However, this tool does not run without errors: On the one hand, some parts are not recognized as narrow, on the other hand large and compact polygons are classified as narrow. Repeated execution of the tool does not solve this but repairing and densifying the input minimizes the errors at least (ESRI 2019). To solve this, all polygons classified as narrow with a ratio of shape length/area $\leq 0.15$ are reclassified as non-narrow while 


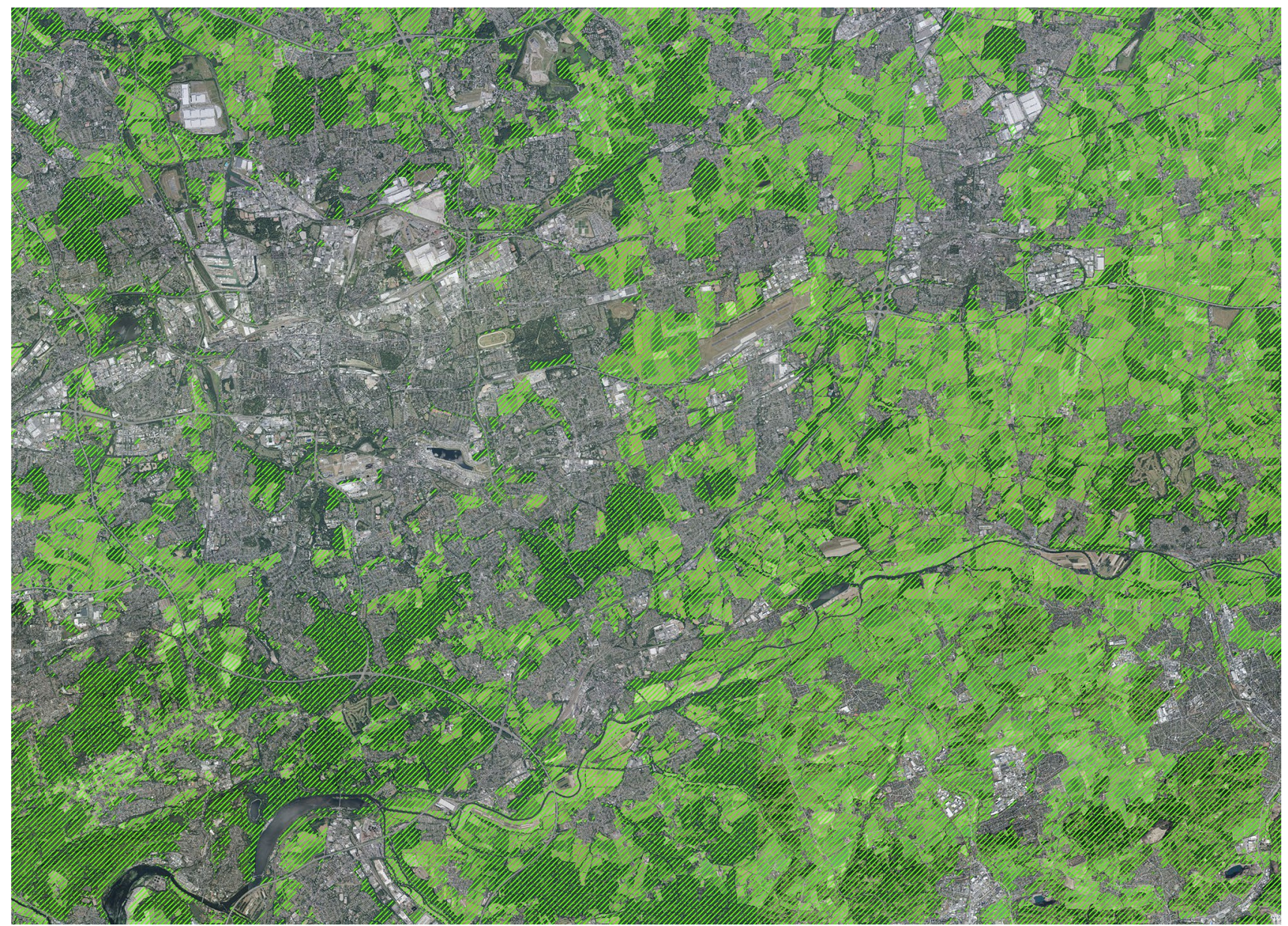

Fig. 7 Overview of the resulting Positive Layer (green), overlaying orthophotos of Westphalia. The urban areas, such as the city of Dortmund (top left), are removed whereas rural areas are preserved (southwest-northeast) for archeological prospection (Land NRW)

undetected narrow parts have to be accepted. Regarding the total area of Westphalia and the misclassifications relating only to these errors, however, their number is insignificant.

4. Finally, the remaining polygons are smoothed very slightly, mostly to be more pleasant to the eye when using the Positive Layer for manual inspection.

The remaining polygons are filtered again using the ratio of shape length/area, this time considering the whole geometry. For this purpose, the previously untouched burial mounds from the DLM and from the FuPu-Delos database (almost 4000) are used to determine the values of the polygons where already known mounds are located. This way, a threshold of (again) $\leq 0.15$ turns out to be reasonable.

Using this threshold raises the minimum polygon size to $573 \mathrm{~m}^{2}$, which corresponds to $24 \mathrm{~m}$ edge length for a square shape. This may seem (too) coarse, as burial mounds in Westphalia often measure around $8 \mathrm{~m}$ in diameter, but it is questionable that such small and isolated areas surrounded by negative areas still contain unknown field monuments. The danger of misclassification is much higher. Figures 7 and 8 illustrate the final Positive Layer.

\section{Evaluation}

The main goal of using this Positive Layer is the reduction of the area to be investigated along with the number of misclassifications. This is associated with an expected increase in precision, representing the portion of correctly classified monuments of all classifications. Both is analyzed in this section.

Reference data were generated manually based on FuPuDelos, the database of archeological records in Westphalia, as well as multiple terrain models and orthophotos. The records have been collected over decades and were not supposed to be used in automated classification and evaluation approaches in the first place. As evaluation is done in a GIS, flagging all results that include a reference point as true, the 


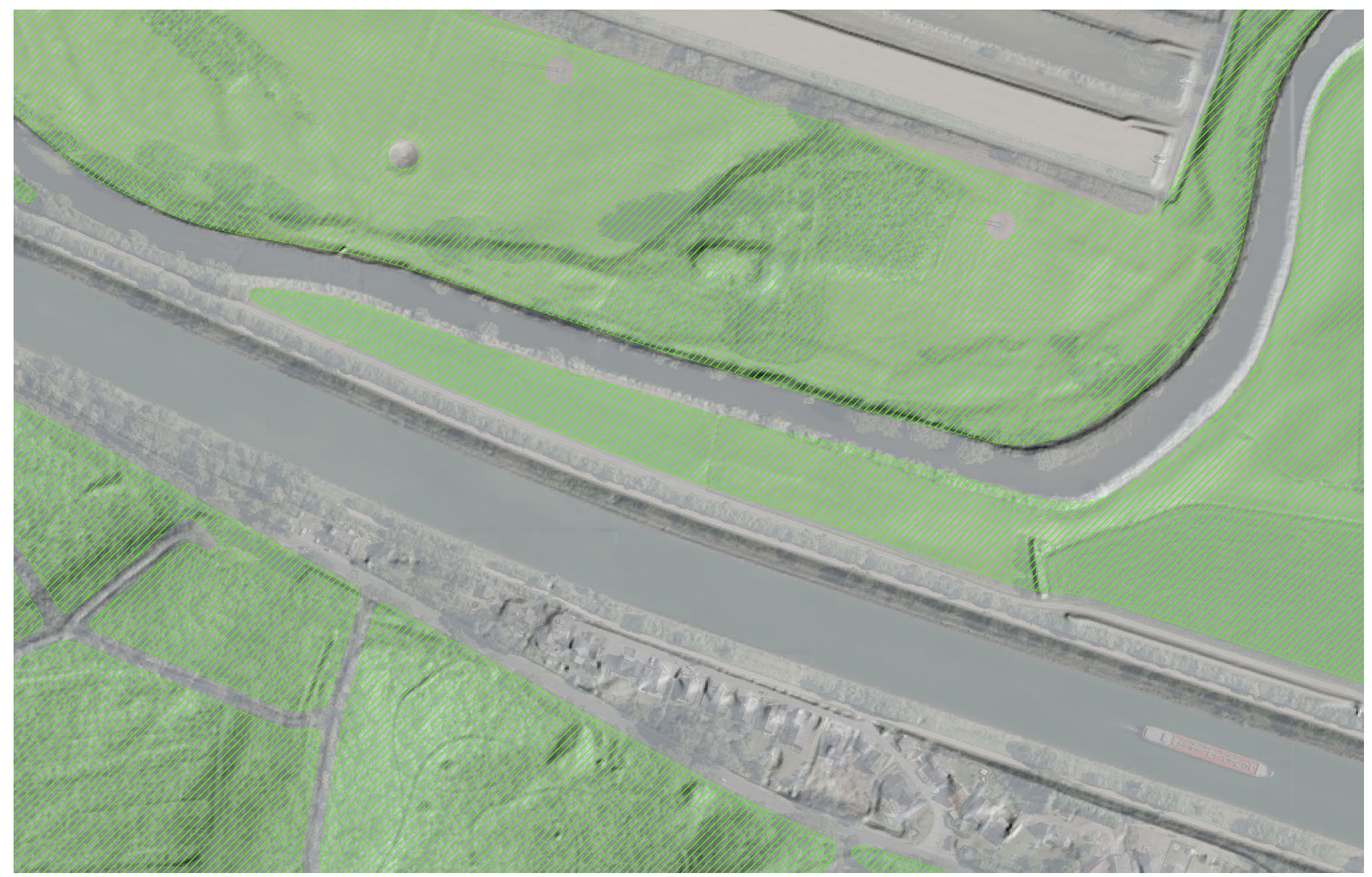

Fig. 8 Detailed view of the resulting Positive Layer (green), overlaying orthophotos and a DTM of the investigation area in Haltern (Sect. 4). Natural and artificial waterbodies, settlements (bottom) and industrial facilities (top) are removed. The same applies for roads, paths (bottom), artificial wells and transmission towers (top left) (Land NRW)

Table 8 Overview of the classes that represent the burial mounds by their degree of erosion

\begin{tabular}{|c|c|c|c|c|c|}
\hline Feature / Class & 1) ideal & \multicolumn{3}{|c|}{} & 5) eroded \\
\hline Area & & $\geq 85 \ldots \leq 320$ & & & $\geq 20 \ldots \leq 500$ \\
\hline Compactness & & $\leq 1.5$ & $\leq 1.6$ & $\leq 1.8$ & $\leq 2$ \\
\hline Elliptic fit & & $\geq 0.86$ & $\geq 0.8$ & $\geq 0.7$ & $\geq 0.6$ \\
\hline Length/Width & $\leq 1.13$ & $\leq 1.25$ & $\leq 1.4$ & $\leq 1.6$ & $\leq 2$ \\
\hline Roundness & & $\leq 0.25$ & $\leq 0.4$ & $\leq 0.6$ & $\leq 1$ \\
\hline Shape index & $\leq 1.25$ & $\leq 1.4$ & $\leq 1.6$ & $\leq 1.85$ \\
\hline Mean & & $\geq 0.2 \ldots \leq 1.2$ & $\ldots \leq 1.35$ & $\ldots \leq 1.45$ & $\geq 0.15 \ldots \leq 1.55$ \\
\hline Max Pixel Value & $\geq 0.5 \ldots \leq 1.65$ & $\geq 0.48 \ldots$ & $\geq 0.45 \ldots$ & $\geq 0.38 \ldots \leq 2$ \\
\hline Min Pixel Value & $\geq-0.1 \ldots \leq 0.85$ & & & $\geq-0.15 \ldots \leq 1.15$ \\
\hline Stand. Deviation & $\geq 0.2$ & $\geq 0.1 \ldots \leq 0.38$ & & & $\geq 0.05 \ldots \leq 0.45$ \\
\hline
\end{tabular}

Segmentation settings: 6/0.001/0.1 (scale/shape/compactness)

If no class border is specified, the border of the next wider class (to the right) is applied.

digital reference mounds were corrected manually to create a reliable data set. At first, points that were offset of their real-world counterparts were moved to the correct position. Second, as some mounds were destroyed between their record and the acquisition of the terrain model, outdated points were removed. Vice versa (thirdly), missing points were added for mounds that were missing in the reference data set. The final set used here consists of 188 mounds.

\subsection{Burial Mound Classification}

Measurements are taken from a burial mound classification, as mounds are easy to count and therefore appropriate for 
Table 9 Reduction of investigation area and false positives in the test site in Haltern

\begin{tabular}{|l|c|c|c|c|c|c|}
\hline & \multicolumn{2}{|c|}{ Westphalia \& Lippe } & \multicolumn{3}{c|}{ Haltern - burial mound detection } \\
\hline Removing $\ldots$ & \multicolumn{2}{|c|}{ Area } & \multicolumn{2}{c|}{ Area } & False Positives (FP) \\
\hline & $21442 \mathrm{~km}^{2}$ & $100 \%$ & $140.0 \mathrm{~km}^{2}$ & $100 \%$ & 2431 & $100 \%$ \\
\hline Polygons & $17657 \mathrm{~km}^{2}$ & $82.3 \%$ & $112.3 \mathrm{~km}^{2}$ & $80.2 \%$ & 1716 & $70,59 \%$ \\
\hline Lines & $16088 \mathrm{~km}^{2}$ & $75 \%$ & $100.6 \mathrm{~km}^{2}$ & $71.8 \%$ & 1667 & $68,57 \%$ \\
\hline Points & $16078 \mathrm{~km}^{2}$ & $74.9 \%$ & $100.5 \mathrm{~km}^{2}$ & $71.7 \%$ & 1647 & $67,75 \%$ \\
\hline Dumpsites & $16000 \mathrm{~km}^{2}$ & $74.6 \%$ & $99.0 \mathrm{~km}^{2}$ & $70.7 \%$ & 1627 & $66,93 \%$ \\
\hline Size \& Shape & $15884 \mathrm{~km}^{2}$ & $74 \%$ & $98.2 \mathrm{~km}^{2}$ & $70.1 \%$ & 1580 & $64,99 \%$ \\
\hline
\end{tabular}

The highlighted columns are visualized in Fig. 9

Fig. 9 Visualized reduction of investigation area and false positives in the test site in Haltern. The graphs correspond to the highlighted columns in Table 9

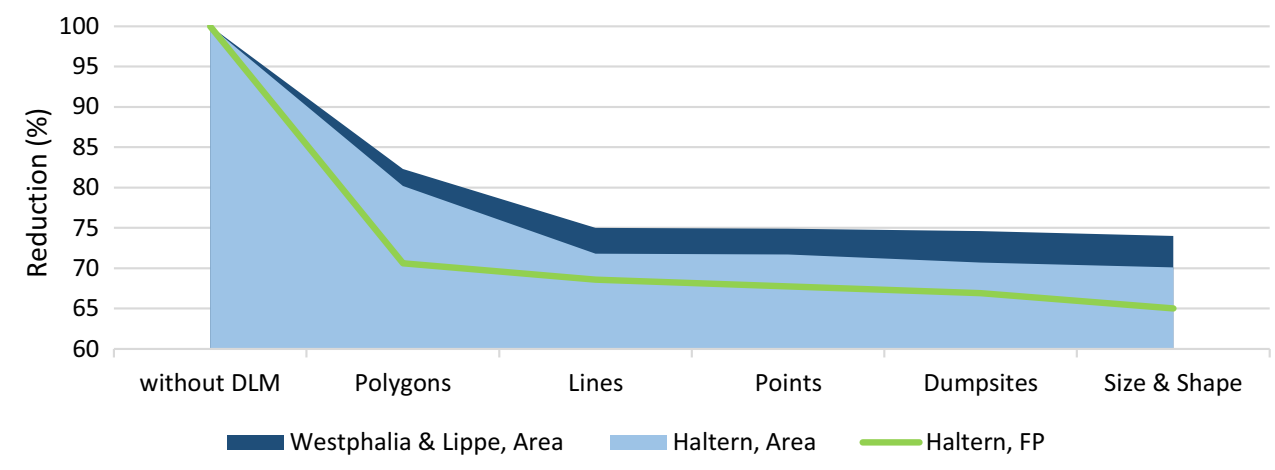

Table 10 Evaluation of the burial mound detection in Haltern

\begin{tabular}{|c|c|c|c|c|c|c|c|c|c|c|c|c|c|c|c|c|c|c|}
\hline & \multicolumn{3}{|c|}{ no BasisDLM } & \multicolumn{3}{|c|}{ Polygons } & \multicolumn{3}{|c|}{ Lines } & \multicolumn{3}{|c|}{ Points } & \multicolumn{3}{|c|}{ Dumpsites } & \multicolumn{3}{|c|}{ Size \& Shape } \\
\hline Class & $\mathrm{TP}$ & FP & Cor & $\mathrm{TP}$ & FP & Cor & $\mathrm{TP}$ & FP & Cor & $\mathrm{TP}$ & FP & Cor & $\mathrm{TP}$ & FP & Cor & $\mathrm{TP}$ & FP & Cor \\
\hline 1) ideal & 14 & 1 & 93 & 14 & 0 & 100 & 15 & 1 & 94 & 15 & 1 & 94 & 15 & 1 & 94 & 13 & 0 & 100 \\
\hline & 20 & 20 & 50 & 20 & 10 & 67 & 18 & 7 & 72 & 19 & 7 & 73 & 18 & 7 & 72 & 16 & 8 & 67 \\
\hline & 56 & 303 & 16 & 54 & 175 & 24 & 55 & 147 & 27 & 56 & 142 & 28 & 56 & 138 & 29 & 60 & 140 & 30 \\
\hline$\downarrow$ & 38 & 662 & 5 & 38 & 466 & 8 & 38 & 433 & 8 & 37 & 431 & 8 & 38 & 431 & 8 & 38 & 409 & 9 \\
\hline 5) eroded & 27 & 1445 & 2 & 27 & 1065 & 2 & 25 & 1079 & 2 & 25 & 1066 & 2 & 25 & 1050 & 2 & 26 & 1023 & 2 \\
\hline
\end{tabular}

Colors correspond to the graphs in Fig. 10

$\mathrm{TP}=$ true positives, $\mathrm{FP}=$ false positives, Precision $=\mathrm{TP} /(\mathrm{TP}+\mathrm{FP})$ in $\%$, overall recall is just over $80 \%$ in all stages

Fig. 10 Precision of the mound classes in the course of the Positive Layer generation. Colors correspond to the highlighted cells in Table 10

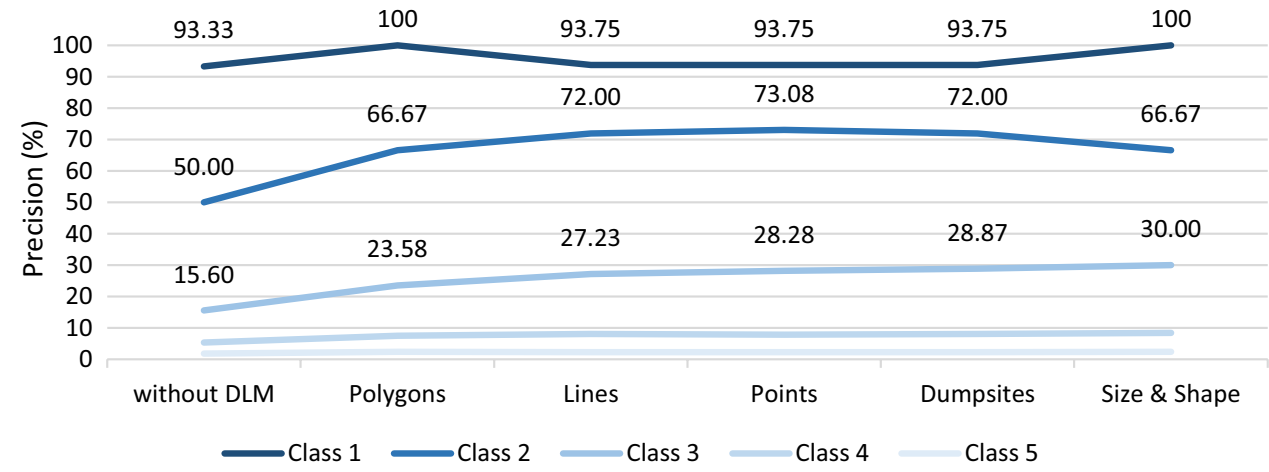


this approach, that uses OBIA and is an updated version of the one performed in Meyer et al. (2019).

Instead of classifying single pixels, OBIA initially merges homogeneous areas by segmenting the image into objects (non-overlapping polygons). As a micro terrain model is investigated, these correspond to areas of similar height above ground level and ideally match a single mound. For every object, features are calculated that directly refer to the object (e.g. length, width, mean pixel value etc.) or describe its relationship to others (e.g. rel. border to brighter [higher] objects), which are used for describing a mound class. Once an object matches the class description, it is further sorted into five different subclasses that corresponds to different degrees of erosion, reaching from (1) ideal to (5) eroded. The idea is to isolate the most promising objects and not to lose any that appear eroded (Table 8).

\subsection{Benefit Quantification of using a Positive Layer}

Table 9 and Fig. 9 provide an overview of the step-bystep reduction of investigation area. Without excluding uninteresting areas, the investigation area in Westphalia is approx. 21,442 $\mathrm{km}^{2}$. Removing unwanted land use classes recorded as polygons (Sect. 3.1) reduces the investigation area significantly to $17,657 \mathrm{~km}^{2}$, corresponding to a decrease of almost $18 \%$. Removing areas around linearly recorded landscape elements (Sect. 3.2) reduces the area again to $16,088 \mathrm{~km}^{2}$, corresponding to a further decrease of $7 \%$ compared to the total area. Subtracting areas around point shaped features (Sect. 3.3) reduces the investigation area by another $10 \mathrm{~km}^{2}(0.1 \%)$. Areas listed in the dumpsite data sets (Sect. 3.4) lead to a reduction of $78 \mathrm{~km}^{2}$ $(0.3 \%)$. The final filtering and reshaping of the remaining Positive Layer is responsible for another $116 \mathrm{~km}^{2}(0.6 \%)$. Compared to the total area of Westphalia, only $74 \%$ are left for further investigation.

A similar trend is to be observed in the investigation area in Haltern. Removing polygons reduces its area by $20 \%$, considering lines by another $8 \%$. The last three steps are again of little importance and finally, the area is reduced from 140 to $98.2 \mathrm{~km}^{2}$, corresponding to an overall decrease of almost $30 \%$. Deviations from the reduction related to the whole region of Westphalia and Lippe are due to the unique land use composition of every investigation area and will turn out differently in other areas.

In this area, the decrease of misclassifications is investigated as well. The records show that the number of misclassifications decrease to around $65 \%$, which is a similar drop to that of the area. As expected, the more area is removed, the more misclassifications are avoided. The correlation is lowest in the line filtering step, which is probably due to burial mounds being point-shaped objects that hardly benefit from removing linear objects from the DTM. Vice versa, when removing points, misclassifications reduce more than the investigation area. When capturing linear field monuments, the described effect should therefore be opposite.

After looking at misclassifications, the actually more interesting True Positives and the precision are also revealing. Results from the mound classification are classified by their degree of erosion in multiple classes to distinguish particularly interesting results from the total and at the
Fig. 11 Example of a perfect mound structure (green) that was rejected using the Positive Layer as it is the inner part of a roundabout (Land NRW)

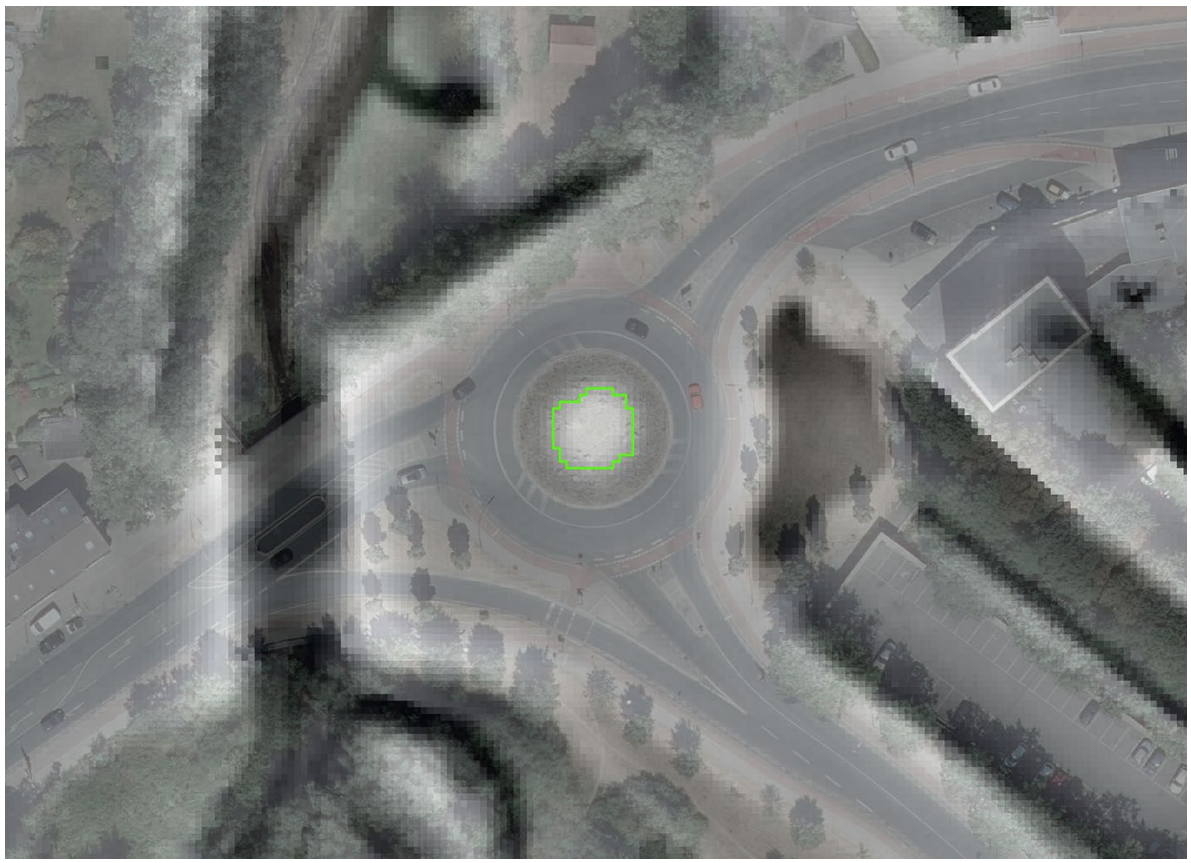


Fig. 12 Example of a sand pile that cannot be rejected using the Positive Layer as it is located in an unsealed agricultural area (Land NRW)
Fig. 13 The building in the upper left corner of the yellow polygon was not yet included in the BasisDLM while generating the Positive Layer (Land NRW)
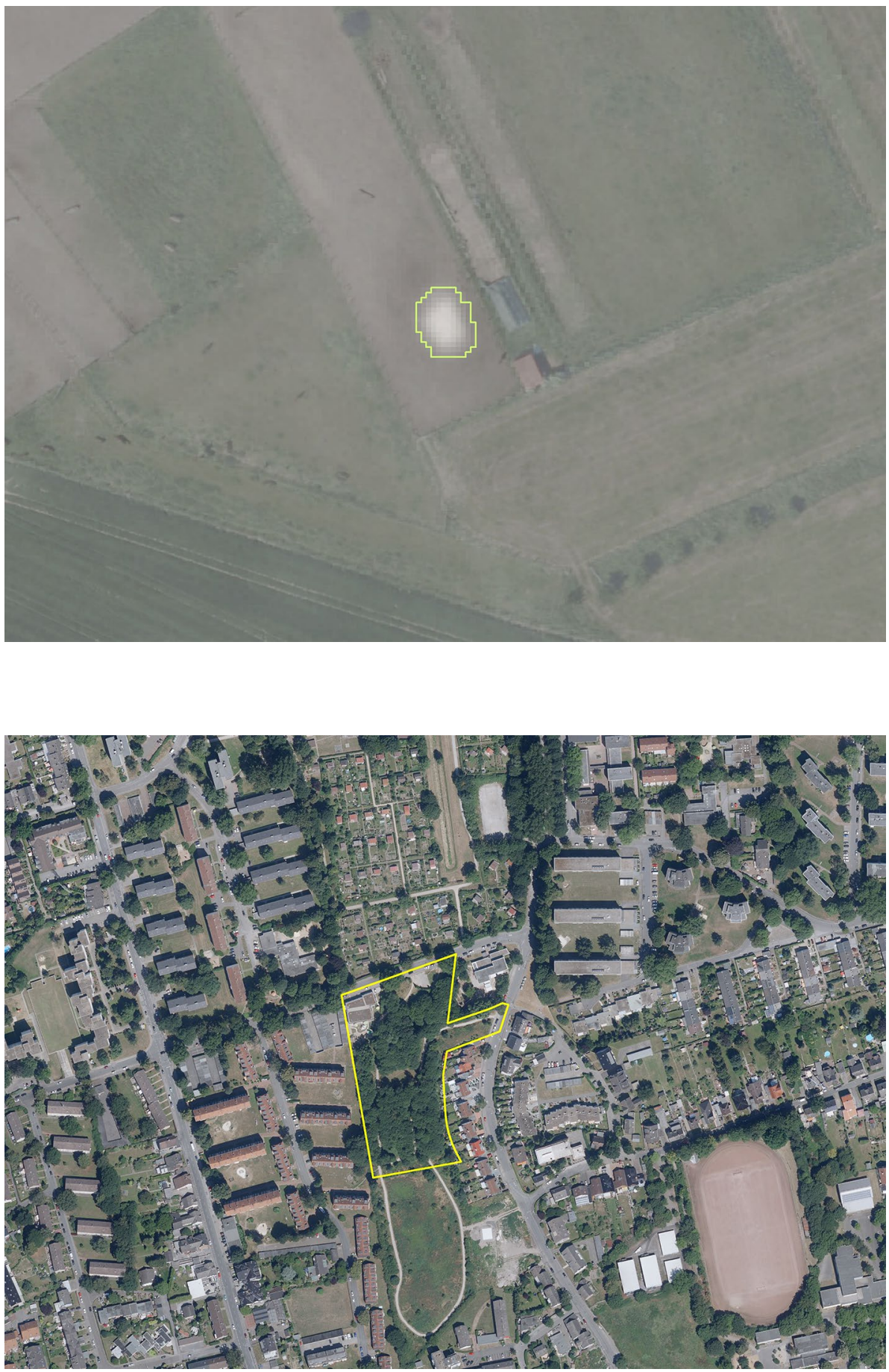

same time not to lose mounds looking like eroded reference mounds.

A reduction of misclassifications (false positives) usually leads to an increasing precision. As shown in Table 10 and Fig. 10, this is the case in all five classes. However, there is a temporary reduction between the single steps of area removal to be observed. This is for example caused by reference mounds that are cut by paths and therefore removed from the Positive Layer.

Reducing the investigation area usually leads to decreasing processing times as well. This could not be measured as the investigation area in Haltern is too small and processing time too short to produce robust results. Furthermore, the 


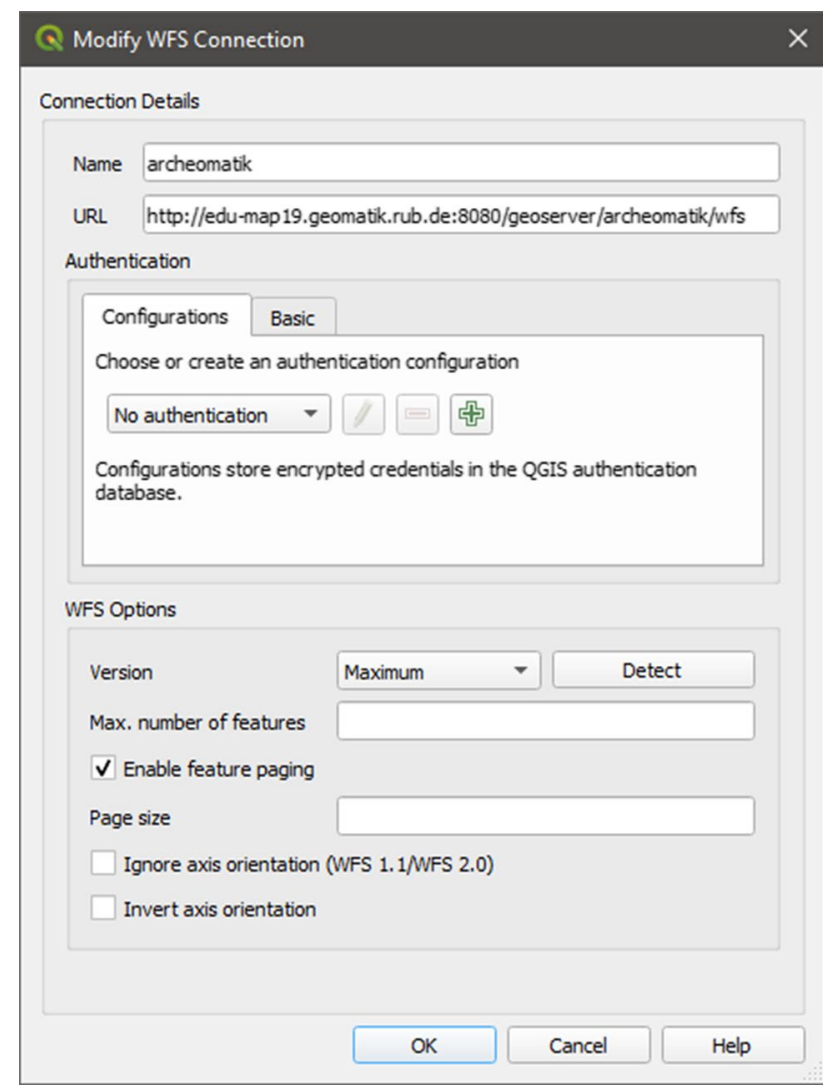

Fig. 14 Access to the WFS in QGIS

time benefit is dependent on the individual hardware that was used and on the way that the Positive Layer is implemented into the workflow. Two oppositional examples of these possibilities shall explain this uncertainty:

The layer could be used as a mask to cut out negative areas from a DTM before it is transferred to a classification software such as eCognition. This would reject all information of the negative areas (regardless of whether it could still be useful or not) and lead to data gaps that might interfere with certain techniques such as template matching (when the template overlaps these gaps). Alternatively, it could be used after the classification for rejecting results that are located in negative areas, which allows using the additional information.

\section{Discussion, Conclusion and Outlook}

Finally, there are a few insights and recommendations to be derived. First of all, removing polygon features has the most beneficial impact while requiring the least effort. Therefore, this should be carried out in every investigation area. Further steps could be chosen depending on the field monument to be detected. While filtering out uninteresting point features is reasonable when searching for point objects such as burial mounds and line filtering appears optional, the latter probably makes far more sense when searching for linear objects, whereas point filtering can be ignored.

A significant number of misclassifications can be avoided using the Positive Layer (Fig. 11), improving the overall precision of presumably all kinds of classification approaches. The specific benefit depends on the character of the investigation area and will turn out differently everywhere, being lower in rural areas compared to those including human settlements.

Apart from automated classification approaches, the Positive Layer is also helpful for manual interpretation of all kinds of remote sensing data sets as it provides the information whether a structure of interest is part of a modern infrastructure or whether it was manipulated in recent times.

The latter is leading over to the drawbacks, as the Positive Layer does not contain any temporal information, for example if an area was exposed to anthropogenic relief changing activities in modern times. As shown in Fig. 6, the Positive Layer would benefit from including information from other layers, especially those including temporal information.

The quality of the Positive Layer is limited by the data from which it was generated. This refers to temporary relief changes in unsealed areas (Fig. 12), recent land cover changes, that are recorded with a little delay (Fig. 13) as well as data gaps (Fig. 6) or plain misclassifications.

Its purpose is only to determine whether an area is of interest for prospection and lacks any information that were initially included in the DLM. Adding these again seems not reasonable as the feature borders would not match anymore. Adding information of all intersecting land use features would lead to ambiguous results as attribute connections would be established that do not exist in the DLM. Therefore, the most reasonable possibility is to overlay the Positive Layer with feature classes of the DLM and manually identify corresponding land uses if necessary.

As the advantages outweigh these drawbacks by far, the derived Positive Layer will be used for further activities towards the greater project goal of a comprehensive detection of field monuments in Westphalia and Lippe. The next step is to choose a reliable combination of visualization and classification to be performed on a larger investigation area. This will furthermore reveal the time-saving aspect of the Positive Layer that is presumably significant.

This workflow could be transferred in different ways: An application to other regions in North Rhine-Westphalia or other federal states for the same archeological purpose is possible as the datasets are organized in the same structure. As this would mean repeated execution of a complex and tedious workflow, the development of a GIS-tool would be helpful, using automation techniques such as 
graphical model builders or Python. Data sets such as the BasisDLM furthermore allow numerous non-archeological applications. For example, all kinds of classifications could be limited to certain land cover such as forest or agricultural land independently of the data basis. Other than that, a repeated assessment of the BasisDLM could support change detections based on remote sensing.

\section{Publication of the Positive Layer}

As the introduced Positive Layer was produced based on Open Geodata, it is supposed to be accessible free of charge. Therefore, the data is published as a WFS (Web Feature Service) to be accessible (Fig. 14). A brief manual on how to access the Positive Layer using QGIS or ArcMap is to be found here: https://ruhr-uni-bochum.scieb o.de/s/ofCU15jM8wk5f8N.

Acknowledgements Open Access funding provided by Projekt DEAL. The author thanks Carsten Jürgens (RUB), Ingo Pfeffer and Michael Rind (both LWL) for their support and supervision of the Ph.D. project, Dennis Edler (RUB) for valuable feedback to this article and Andreas Redecker (RUB) for publishing the generated data.

\section{Compliance with Ethical Standards}

Conflict of interest The author declares no conflict of interest or competing interests. Other declarations to not apply.

Open Access This article is licensed under a Creative Commons Attribution 4.0 International License, which permits use, sharing, adaptation, distribution and reproduction in any medium or format, as long as you give appropriate credit to the original author(s) and the source, provide a link to the Creative Commons licence, and indicate if changes were made. The images or other third party material in this article are included in the article's Creative Commons licence, unless indicated otherwise in a credit line to the material. If material is not included in the article's Creative Commons licence and your intended use is not permitted by statutory regulation or exceeds the permitted use, you will need to obtain permission directly from the copyright holder. To view a copy of this licence, visit http://creativecommons.org/licenses/by/4.0/.

\section{References}

AdV (2008) Dokumentation zur Modellierung der Geoinformationen des amtlichen Vermessungswesens (GeoInfoDok). ATKIS-Katalogwerke. ATKIS-Objektartenkatalog Basis-DLM. NRW-Erfassung. Version 6.0. https://www.bezreg-koeln.nrw. de/brk_internet/geobasis/landschaftsmodelle/basis_dlm/objek tartenkatalog.pdf. Accessed 23 Jan 2019

Bezirksregierung Köln (2019) Digitales Basis-Landschaftsmodell (Basis-DLM). https://www.bezreg-koeln.nrw.de/brk_internet/ geobasis/landschaftsmodelle/basis_dlm/index.html. Accessed 11.9.2019

Bofinger J, Kurz S, Schmidt S (2007) Hightech aus der Luft für Bodendenkmale-Airborne Laserscanning (LIDAR) und
Archäologie. Denkmalpflege in Baden-Württemberg Nachrichtenblatt der Landesdenkmalpflege 36(3):153-158

Braasch O (1983) Luftbildarchäologie in Süddeutschland-Spuren aus römischer Zeit. Würtemberg, Landesmuseum, Stuttgart

Brouwer S (2015) Ermittlung von Wölbäckern aus dem Digitalen Geländemodell mit ArcGIS-Eine Reliefanalyse zur Rekonstruktion historischer Landnutzung in NRW. Unpublished Master's Thesis, Hochschule Osnabrück and Universität Osnabrück

Canuto MA, Estrada-Belli F, Garrison TG, Houston SD, Acuña MJ, Kováč M, Marken D, Nondédéo P, Auld-Thomas L, Castanet C, Chatelain D, Chiriboga CR, Drápela T, Lieskovský T, Tokovinine A, Velasquez A, Fernández-Díaz JC, Shrestha R (2018) Ancient lowland Maya complexity as revealed by airborne laser scanning of northern Guatemala. Science 361(6409):eaau0137. https://doi.org/10.1126/science.aau0137

Cerrillo-Cuenca E (2017) (2017) An approach to the automatic surveying of prehistoric barrows through LiDAR. Quat Int 435:135-145. https://doi.org/10.1016/j.quaint.2015.12.099

Crutchley S (2006) Light detection and ranging (lidar) in the Witham Valley, Lincolnshire-an assessment of new remote sensing techniques. Archaeol Prospect 13:251-257. https://doi. org/10.1002/arp.294

Davis D, Sanger M, Lipo C (2019) Automated mound detection using lidar and object-based image analysis in Beaufort County, South Carolina. Southeast Archaeol 38(1):23-37. https://doi. org/10.1080/0734578X.2018.1482186

De Boer A (2007) Using pattern recognition to search LIDAR data for archeological sites. In: Figueiredo A, Velho G (eds) The world is in your eyes-CAA2005-computer applications and quantitative methods in archaeology-proceedings of the 33rd conference, Tomar, March 2005. CAA Portugal, Tomar, pp 245-254 (ISBN: 97898995313)

Devereux B, Amable G, Crow P, Cliff A (2005) The potential of airborne lidar for detection of archaeological features under woodland canopies. Antiquity 79:648-660. https://doi.org/10.1017/ S0003598X00114589

Devereux B, Amable G, Crow P (2008) Visualisation of LiDAR terrain models for archaeological feature detection. Antiquity 82:470-479. https://doi.org/10.1017/S0003598X00096952

Doneus M (2013) Openness as visualization technique for interpretative mapping of airborne lidar derived digital terrain models. Remote Sens 5(12):6427-6442. https://doi.org/10.3390/rs512 6427

Doneus M, Briese C (2006) Full-waveform airborne laser scanning as a tool for archaeological reconnaissance. In: Campana $\mathrm{S}$, Forte M (eds) From space to place-2nd international conference on remote sensing in archaeology-proceedings of the 2nd international workshop, CNR, Rome, Italy, December 4-7, 2006. Archaeopress, Oxford, pp 99-105 (ISBN: 1841719986)

Doneus M, Briese C, Fera M, Janner M (2008) Archaeological prospection of forested areas using full-waveform airborne laser scanning. J Archaeol Sci 35:882-893. https://doi.org/10.1016/j. jas.2007.06.013

ESRI (2019) ArcGIS Pro Help-Identify Narrow Polygons. https:// pro.arcgis.com/de/pro-app/tool-reference/topographic-production /identify-narrow-polygons.htm. Accessed 11 Sept 2019

European Commission (2007) - Directive 2007/2/EC of the European Parliament and the of the council of 14 March 2007 establishing and Infrastructure for Spatial Information in the European Community (INSPIRE). https://eur-lex.europa.eu/legal-content/ EN/TXT/PDF/?uri=CELEX:32007L0002\&qid=1581958705 $103 \&$ from $=$ EN. Accessed 17 Feb 2020

Freeland T, Heung B, Burley D, Clark G, Knudby A (2016) Automated feature extraction for prospection and analysis of monumental earthworks from aerial LiDAR in the Kingdom of Tonga. J Archaeol Sci 69:64-74. https://doi.org/10.1016/j.jas.2016.04.011 
Geologischer Dienst Nordrhein-Westfalen (2019) Abgrabungsmonitoring NRW. https://www.gd.nrw.de/ro_am.htm. Accessed 11 Sept 2019

Hake G, Grünreich D, Meng L (2002) Kartographie-visualisierung raum-zeitlicher Informationen. De Gruyter, Berlin (ISBN: 3-11-016404-3)

Heinzel J, Sittler B (2010) LiDAR surveys of ancient landscapes in SW Germany-assessment of archaeological features under forests and attempts for automatic pattern recognition. In: Campana $\mathrm{S}$, Forte M, Liuzza C (eds) Space, time, place-third international conference on remote sensing in archaeology. Archaeopress, Oxford, pp 113-121 (ISBN: 1407306596)

Hesse R (2010) LiDAR-derived local relief models-a new tool for archaeological prospection. Archaeol Prospect 17:67-72. https:// doi.org/10.1002/arp.374

Hesse R (2016) Visualisierung hochauflösender Digitaler Geländemodelle mit LiVT. In: Lieberwirth U, Herzog I (eds) 3D-Anwendungen in der Archäologie — computeranwendungen und quantitative Methoden in der Archäologie-workshop der AG CAA und des Exzellenzclusters Topoi 2013. Edition Topoi, Berlin, pp 109-128 (ISBN: 978-3-9816751-4-6)

Holden N (2001) Digital airborne remote sensing - the principles of LIDAR and CASI. AARGnews 22:23-24

Holden N, Horne P, Bewley R (2002) High-resolution digital airborne mapping and archaeology. In: Bewley R, Raczkowski M (eds) Aerial archaeology_developing future practice. IOS Press, Amsterdam, pp 173-180 (ISBN: 427490475X)

Klinke L, Pfeffer I (2018) Kontinuität zahlt sich aus-zum Fortgang der ALS-Projektion in Westfalen-Lippe. In: Rind M, Dickers A (eds) Archäologie in Westfalen-Lippe 2017. Beier \& Beran, Langenweißbach, pp 259-261 (ISBN: 978-3-95741-096-2)

Kokalj Ž, Hesse R (2017) Airborne laser scanning raster data visualization-a guide to good practice. Založba ZRC, Ljubljana (ISBN: 978-961-254-984-8)

LAND NRW (2019) Data licence Germany: dl-de/by-2-0 (https://www. govdata.de/dl-de/by-2-0). https://www.opengeodata.nrw.de/produ kte. Accessed 11 Sept 2019

LANUV NRW (2019) (Open) ADDISweb-Abfalldeponiedaten-Informationssystem. https://www.addis.nrw.de. Accessed 19 Nov 2019

LWL-Archäologie für Westfalen (2019) FuPu-Delos. https://www.lwl. org/delos/?m=fupu

Meyer MF, Pfeffer I, Jürgens C (2019) Automated detection of field monuments in digital terrain models of westphalia using OBIA. Geosciences 9(3):109. https://doi.org/10.3390/geosciences9030 109

Ministerium des Innern des Landes Nordrhein-Westfalen (2020) Gesetz zum Schutz und zur Pflege der Denkmäler im Lande NordrheinWestfalen. Stand: 31.1.2020. https://recht.nrw.de/lmi/owa/br_ text_anzeigen?v_id=5720031106092634017. Accessed $17 \mathrm{Feb}$ 2020
Motkin D (2001) An assessment of LIDAR for archaeological use. AARGnews 22:24-25

NASA (2019) SRTM (Shuttle Radar Topography Mission). https:// www2.jpl.nasa.gov/srtm. Accessed 11 Sept 2019

Noack D. (2019) GIS-gestützte Analyse zum Wölbackervorkommen in der Prignitz. Unpublished Master's Thesis, Universität Salzburg

Risbøl O, Gjertsen A, SkareK (2006) Airborne laser scanning of cultural remains in forests-some preliminary results from a Norwegian project. In: Campana S, Forte M (eds) From space to place-2nd international conference on remote sensing in archaeology - proceedings of the 2nd international workshop, CNR, Rome, Italy, December 4-7, 2006. Archaeopress, Oxford, pp 107-112 (ISBN: 1841719986)

Schmidt J, Werther L, Zielhofer C (2018) Shaping pre-modern digital terrain models - the former topography at Charlemagne's canal construction site. PLoS ONE 13(7):e0200167. https://doi. org/10.1371/journal.pone.0200167

Schneider A, Takla M, Nicolay A, Raab A, Raab T (2015) A template-matching approach combining morphometric variables for automated mapping of charcoal kiln sites. Archaeol Prospect 22:45-62. https://doi.org/10.1002/arp.1497

Sevara C, Pregesbauer M, Doneus M, Verhoeven G, Trinks I (2016) Pixel versus object-a comparison of strategies for the semiautomated mapping of archaeological features using airborne laser scanning data. J Archaeol Sci Rep 5:485-498. https://doi. org/10.1016/j.jasrep.2015.12.023

Sittler B (2004) Revealing historical landscapes by using airborne laser scanning - a 3-D modell [sic!] of ridge and furrow in forests near Rastatt (Germany). In: Thies M, Koch B, Spiecker H, Weinacker $\mathrm{H}$ (eds) Laser-scanners for forests and landscape assessment, Freiburg, pp 258-261 (ISSN: 1682-1750)

Trier $\varnothing$, Zortea M, Tonning C (2015) Automatic detection of mound structures in airborne laser scanning data. J Archaeol Sci Rep 2:69-79. https://doi.org/10.1016/j.jasrep.2015.01.005

Trier $\emptyset$, Cowley D, Waldeland A (2018) Using deep neural networks on airborne laser scanning data-results from a case study of semi-automatic mapping of archaeological topography on Arran, Scotland. Archaeol Prospect 26(2):1-11. https://doi.org/10.1002/ $\operatorname{arp} .1731$

Verschoof-van der Vaart W, Lambers K (2019) Learning to look at LiDAR - the use of R-CNN in the automated detection of archaeological objects in LiDAR data from the Netherlands. J Comput Appl Archaeol 2(1):31-40. https://doi.org/10.5334/jcaa.32

Vletter W (2015) A workflow for (Semi) automatic extraction of roads and paths in forested areas from Airborne Laser Scan data. AARGNews 50:33-40

Zakšek K, Oštir K, Kokalj Ž (2011) Sky-view factor as a relief visualization technique. Remote Sens 3:398-415. https://doi. org/10.3390/rs3020398 